\title{
VESTIGIOS PATRIMONIALES DEL ASERRADERO CALETA MARÍA, TIERRA DEL FUEGO (CHILE)
}

SAMUEL GARCÍA O.*

\section{RESUMEN}

Fundado en 1942, el aserradero Caleta María fue el último de los grandes establecimientos madereros situado en la costa del fiordo Almirantazgo (Tierra del Fuego, Chile). El objetivo del artículo es el conocimiento de su historia, hasta ahora virtualmente ignorada, a través de los escasos antecedentes compulsados y de los restos de sus instalaciones, que se valoran como elementos del patrimonio histórico cultural fueguino.

PALABRAS CLAVE: explotación maderera, Tierra del Fuego, territorio marginal.

\section{PATRIMONIAL REMAINS OF CALETA MARIA SAWMILL, TIERRA DEL FUEGO (CHILE)}

\begin{abstract}
Founded in 1942, Caleta Maria sawmill was the last of the great lumber stablishments placed in the shore of the Almirantazgo sound (Tierra del Fuego, Chile). The objective of this article is the knowledge of its history, virtually ignored till now, through the few verified precedents and the remains of its instalations, considered as elements of the historical patrimony of Tierra del Fuego.
\end{abstract}

KEY WORDS: lumber exploitation, Tierra del Fuego, marginal territory.

\footnotetext{
* Arquitecto y Licenciado en Arquitectura. Universidad de Magallanes. Investigador asociado al Centro de Estudios del Hombre Austral, Instituto de la Patagonia. samuelgarciaoteiza@gmail.com.
} 


\section{INTRODUCCIÓN}

El extenso, denso y prístino bosque nativo concentrado al sur del paralelo $54^{\circ}$ de Tierra del Fuego (Chile) fue a comienzos del siglo XX objeto de explotación a gran escala. La exclusiva accesibilidad por mar y considerable distancia existente entre algún pueblo o centro urbano del lugar de extracción de la materia prima, sumado la rentabilidad económica de la industria forestal, justificó la creación de nuevos asentamientos explotadores. De tal manera surgieron simultáneamente los aserraderos de Puerto Yartou, Puerto Arturo, Elenita, La Paciencia y Caleta María, los que conformaron un escenario desde el cual se empezó a escribir una nueva historia social y económica de Tierra del Fuego.

Estos asentamientos explotadores destacaron por su capacidad de producción ${ }^{1}$ y la cantidad de personal requerido para desarrollar las faenas, los que al habitar, permanecer y morar, fueron dando vida y dotando de nuevos valores, interpretaciones y significados a estos lugares hasta entonces ausentes de la presencia constante y masiva del hombre blanco.

A inicios de la década del cuarenta los aserraderos de Puerto Yartou ${ }^{2}$, Puerto Arturo y La Paciencia ${ }^{3}$, los cuales llegaron hacer los mayores centros madereros abastecedores de la región magallánica y sur argentino, decayeron significativamente debido a diversos factores ${ }^{4}$ provocando el cese definitivo de sus actividades y su gradual y posterior abandono. Con lo acontecido la actividad forestal a gran escala llegaba a su término y bajo éste adverso contexto tuvo

1 (...) la producción conjunta de estos aserraderos subió de 1.500 .000 p2 madereros antes de 1920 a 2.500 .000 p2 en la temporada 1925/26. Durante la siguiente, la producción cayó a 713.347 p2, recuperándose en 1929/30, período en que alcanzó a 2.051.351 p2. (Martinic, 2009:160).

${ }^{2}$ Iniciado por Alberto Baeriswyl P. en 1908. (Baeriswyl, 2003:32)

${ }^{3}$ Ambos iniciados en 1918 por la Sociedad Anónima Ganadera y Comercial Menéndez-Behety. (Martinic, 2009:123).

${ }^{4}$ La industria maderera en Magallanes: principales causas que ha determinado su actual crisis.

La industria maderera en Magallanes fue durante largos años, después de la ganadería, la que mayor importancia representaba en esta región, proporcionando trabajo a numerosos obreros. Los productos de los aserraderos que funcionaban en distintos puntos del territorio tenían amplio mercado, no solo en este mismo sino que también se exportaban a gran escala a todos los pueblos de la costa Argentina dando a sí flete a los vapores de la matrícula de este puerto.

En los últimos años esta industria, no pudiendo resistir a origen en 1942 el último de los grandes aserraderos del fiordo Almirantazgo; el aserradero Caleta María.

\section{PRIMER ACERCAMIENTO A CALETA MARÍA}

Por su condición natural de remate y convergencia de los valles del río Azopardo y Fontaine, además de su privilegiada conectividad marítima con el resto de la región a través del fiordo Almirantazgo, caleta María adquirió a comienzos del siglo XX la vocación, desde un punto de vista espacial, de pórtico de acceso hacia el interior del tercio sur de Tierra del Fuego. Gracias a esta condición geográfica y espacial, caleta María fue el lugar de partida de las expediciones de los exploradores O'Connor (1892), Nordenskjold (1896), Skottsberg (1908), Luis Carnino (1909)5 , Agostini (1913), Rockwell Kent (1922), que impulsados por la fuerza de lo desconocido se aventuraron por uno de los tantos rincones ignotos del extremo austral fueguino. A pesar de la importancia que tuvo caleta María en el periodo, que justamente podría denominarse período de las expediciones históricas, su posición marginal influyó en el actual vacío de documentación histórica en lo que respecta a su ocupación humana. Como este trabajo no pretende ser más que un primer aporte hacia una comprensión más amplia de su historia, valorizamos las escasas fuentes primarias como los periódicos de la época y diarios de exploradores. En este contexto es Agostini quien nos entrega los primeros datos de presencia humana en caleta María, aunque no la nombra como tal, cuando desembarcó

factores desfavorables que le afectan económicamente, fue perdiendo poco a poco su importancia hasta quedar reducida en la actualidad a mínimas proporciones.

Entre las principales causas que originaron este estado de cosas, mencionaremos las dos siguientes:

Los fuertes derechos aduaneros impuesto por el Gobierno de la República Argentina a la internación de las maderas chilenas produjeron, como consecuencia inmediata, la perdida en su mayor parte de los mercados argentinos que eran los más importantes consumidores de las maderas de Magallanes. Las leyes tributarias, por otra parte, impusieron crecidos desembolsos anuales que no pudieron soportar algunos de los mencionados establecimientos que hubieron que clausurarse. Obtener de la vecina República la supresión o disminución de los derechos de importación y reducir los actuales impuestos tributarios, sería la única eficaz solución que podría darse a este problema para conseguir que volviera a resurgir en Magallanes la industria maderera. (El Magallanes, 19 de febrero 1930).

${ }^{5}$ Ver Massa, 1950 


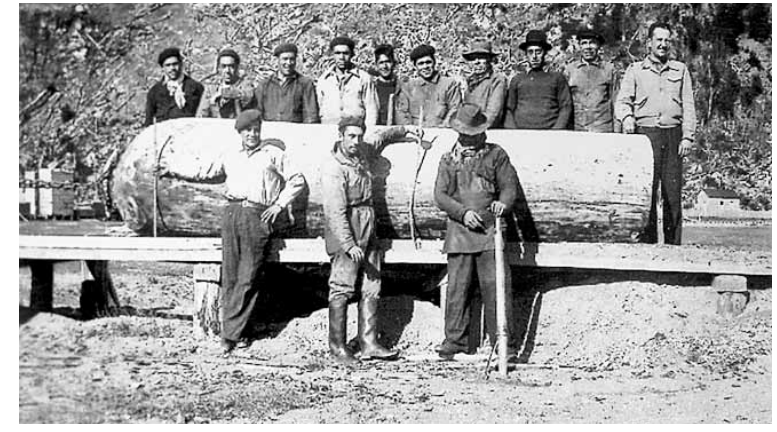

Fig.1. Trabajadores del aserradero Caleta María hacia 1945 (Fotografía de Lucio Genskowski P.).

en este lugar el 19 de febrero de 1913, para iniciar su expedición entre y fiordo Almirantazgo-Ushuaia ${ }^{6}$. En la orilla opuesta encontramos una miserable choza rodeada por un potrero, del que huyeron espantadas algunas ovejas. Es una incipiente estancia momentáneamente abandonada por los colonos los cuales han tomado legítima posesión de aquellas tierras valiéndose del derecho de primer ocupante. ${ }^{7}$

En diciembre de 1949 a consecuencia del movimiento telúrico que afectó a la región de Magallanes, caleta María integró, extensamente, las columnas informativas de los periódicos locales:

Personal del aserradero "Caleta María” pide ayuda

Anoche alrededor de las 24 horas telefónicamente una señora de apellido Velásquez avisó que había captado en su receptor de radio un llamado dirigido a los radioaficionados de Magallanes, desde Caleta María.

De inmediato se puso en conocimiento del radioaficionado y técnico Andrés Nielsen, quien por intermedio de su estación C7 AA y con la frecuencia dada por el señor Alberto Ponchie que posee la estación C E 7 AB, logró ponerse en contacto con la radio de Caleta María, recibiendo del Administrador del aserradero de la firma Marcou y Cía, ubicado en ese lugar, una relación del sismo,

\footnotetext{
${ }^{6}$ Se refiere al río Fontaine.

${ }^{7}$ Agostini,1956:117

${ }^{8}$ El Magallanes, 20 de diciembre 1949.

${ }^{9}$ Caleta María no ha presentado hasta nuestros días tal cantidad de habitantes.

${ }^{10}$ Raúl Arcos Estay (run: 473.062-3) nació el 4/2/1910 en la ciudad de Quillota, se desconoce la fecha de su fallecimiento.
}

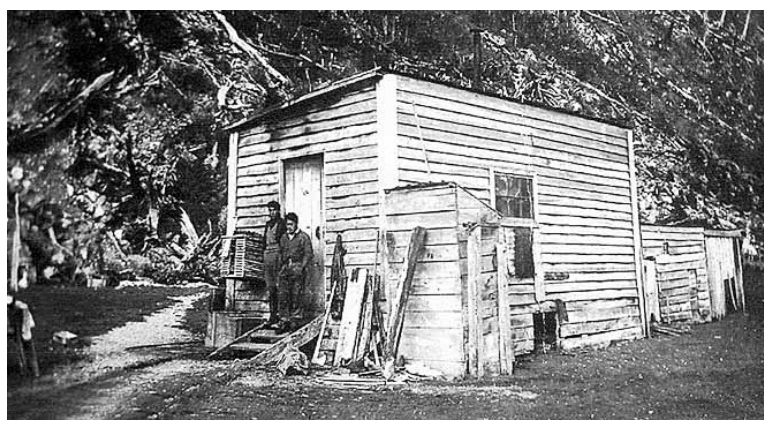

Fig.2. Personal del aserradero Caleta María. 1945 (Fotografía de Lucio Genskowski P.).

especialmente en los destrozos causados por los rodados como igualmente solicitó auxilio por no disponer de víveres necesarios para cincuenta personas ${ }^{9}$ que residen allí.

También anoche tomó contacto con Caleta María el radioaficionado señor Alejandro Andreuzzi por intermedio de su estación C E 7 $A Q$, contribuyendo tener comunicación hasta la madrugada.

\section{Relación de lo ocurrido}

Al mediodía de hoy invitados por el Delegado de los Servicios Eléctricos señor Roberto Bravo, y acompañados de los radioaficionados señores Ponchie, Andreuzzi y Nielsen, por intermedio de la estación C7 AA, mantuvimos una conversación con el Administrador del aserradero afectado, señor Raúl Arcos ${ }^{10}$, quien nos proporcionó gentilmente una versión completa de los hechos.

Después de los saludos de rigor y siendo las 11:30 horas se inició la transmisión. El señor Arcos nos expresó que en esos momentos regresaba de una inspección que realizó por el río Azopardo pudiendo observar que las aguas del Lago Fagnano arrasaron en una extensión de 150 metros con todos los ranchos y árboles adyacentes, recogiéndose después a su centro. También a 15 metros de su desembocadura derribó un puente (Fig.11).

Destrozos producidos

El temblor más fuerte se sintió a las tres de la madrugada del sábado, nos continuó diciendo el Administrador de Caleta María, el cual produjo grandes rodados y grietas en la tierra, por las 


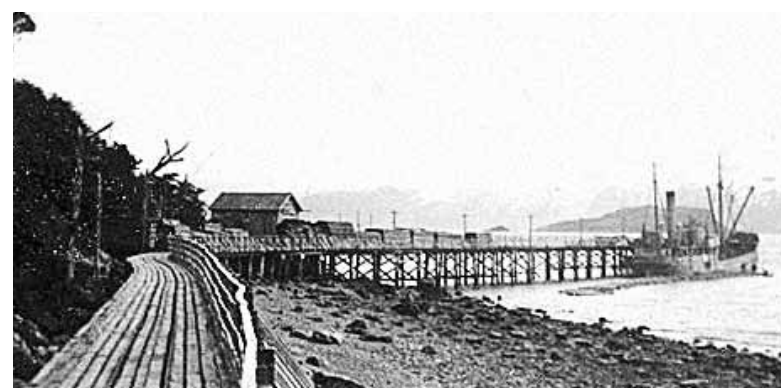

Fig.3. Primer muelle construido en caleta María, 1945 (Fotografía de Lucio Genskowski P.).

cuales emanaban chorros de agua.

La marea se recogió entre 150 y 200 metros observándose grandes olas que hacían temer que al volver las aguas éstas producirían un maremoto, lo que no sucedió felizmente.

Los rodados taparon totalmente la línea que facilita el traslado de maderas hasta el muelle y cinco tambores con nafta explotaron produciéndose un incendio que arrasó con maderas y parte del muelle, siendo las llamas momentos más tarde cubiertas por un rodado lo que permitió que no continuara el siniestro.

Los temblores continuaron sintiéndose desde la madrugada del sábado con intervalos de un minuto y precedidos de fuertes ruidos subterráneos, los que se prolongaron durante todo el día de ayer y a las 3:09 horas de la madrugada de hoy volvió a sentirse con gran fuerza y ocurrieron nuevos deslizamientos de tierra.

\section{Perjuicios en Caleta María}

En la mañana de hoy fuimos invitados por el jefe de la Zona de emergencia, contraalmirante don Rafael Santibáñez Escobar, a una reunión destinada a proporcionarnos las últimas noticias relacionadas con los perjuicios causados en la zona por el movimiento sísmico.

El señor Santibáñez nos informó que en la madrugada de hoy, en la Gobernación Marítima, se recibió una información radial del administrador del aserradero Caleta María, situado en el Seno Almirantazgo señor Raúl Arcos, quien dio cuenta de que durante el día sábado se sucedieron fuertes sacudidas, que continuaron hasta esta mañana.

Como consecuencia de estos movimientos

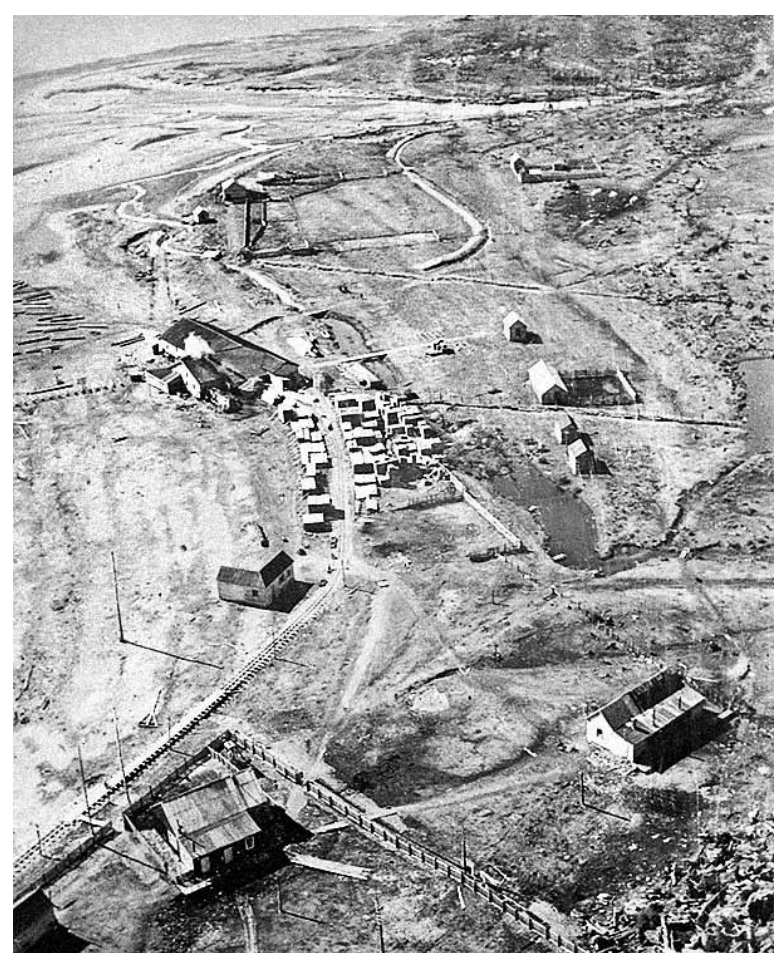

Fig.4. Vista parcial del aserradero Caleta María,1945. Nótese en la esquina superior derecha un puente sobre el río Fontaine (Fotografía de Lucio Genskowski P.).

se produjo el derrumbe de un barranco cayendo sobre el muelle alrededor de 200 toneladas de tierra, que lo hundieron totalmente (Fig.5).

Los estragos causados fueron numerosos, pues a raíz del temblor se reventaron tambores de bencina en una bodega produciéndose un incendio que alcanzó a 700 tablones que hallaban estibados cerca del galpón.

Además quedó inutilizada la cancha de aterrizaje; se desbordó el Lago Fagnano produciéndose el desborde por el Río Azopardo que inundó un valle, arrastrando corrales y un rancho.

\section{No hay víctimas}

Las informaciones llegadas a la gobernación Marítima, hacen saber que no se han producido desgracias personales. Los 50 pobladores de esa zona se encuentran en perfectas condiciones, y a pesar de las pérdidas sufridas, se encuentran con víveres hasta fines de la semana. 


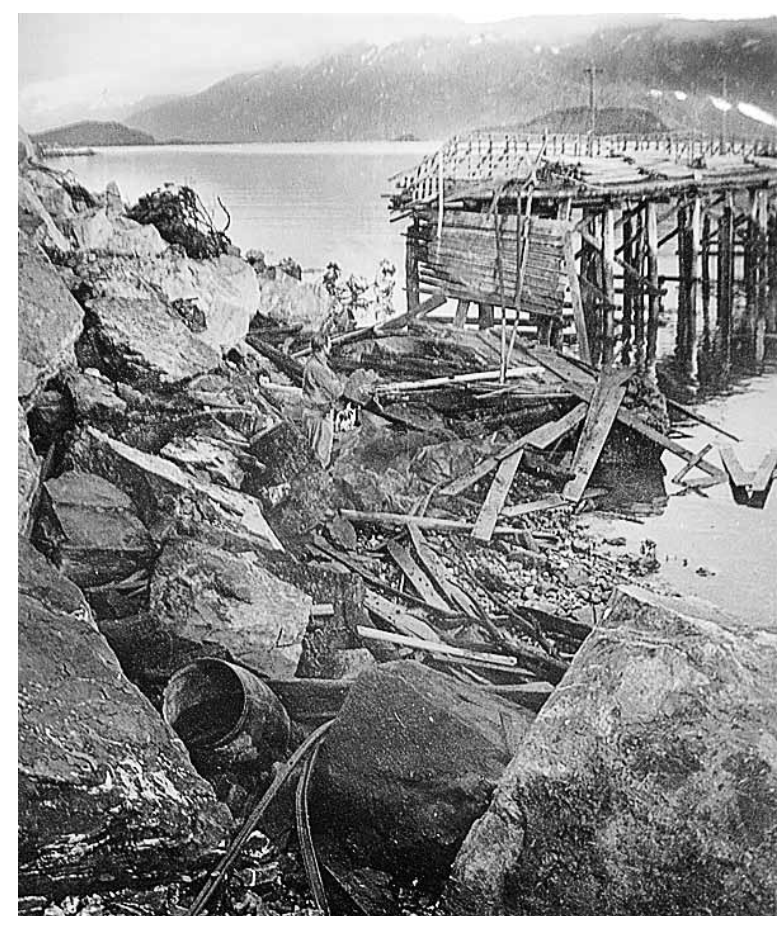

Fig.5. Muelle de caleta María destruido tras el terremoto de 1949. Al centro de la imagen se aprecia un hombre observando lo acontecido

(Fotografía de Lucio Genskowski P.).

Hubo un movimiento de marea, que en un principio causó alarma entre los pobladores, pero que al normalizarse devolvió la tranquilad a los ánimos.

\section{Zarpa el "Lautaro"}

Nos agregó el Almirante Santibáñez que ha dispuesto el zarpe del patrullero "Lautaro" con rumbo al seno del Almirantazgo, con el objeto de visitar a los pobladores de esa zona y prestarle ayuda. El buque lleva además víveres y medicamentos para atender cualquier emergencia.

${ }^{11}$ El Magallanes, 21 de diciembre 1949.

12 Este antecedente da cuenta que caleta María fue un poblado donde no sólo habitaba el personal específico del aserradero sino también sus respectivas familias.

13 Arturo Barrientos arrendó los campos de caleta María entre los años 1973-1978. (García, 2012:41)

${ }^{14}$ Antecedente desconocido en la historia de caleta María. Aún son escasas o nulas las fuentes que informen sobre lo acontecido entre 1913-1942.

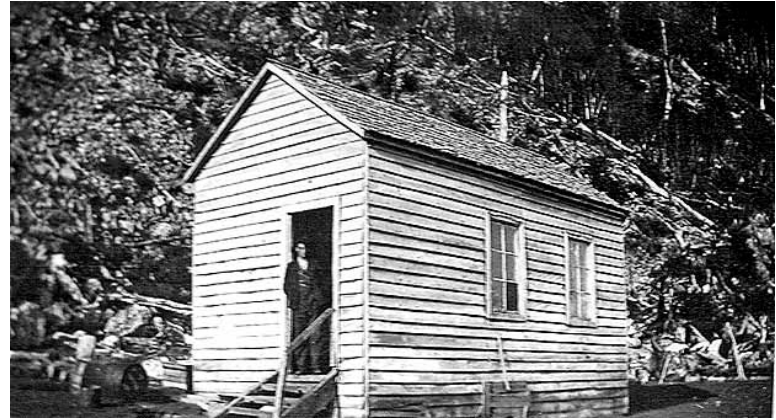

Fig.6. Vivienda en caleta María (fotografía de Lucio Genskowski P.)

La nave recorrerá los establecimientos de Puerto Yartou, La Paciencia, Caleta María, Puerto Harris y otros lugares.

Patrullero Lautaro regresa hoy del seno Almirantazgo ${ }^{11}$

El patrullero "Lautaro" que zarpó ayer de nuestro puerto con destino al Seno Almirantazgo, regresa en la tarde de hoy, trayendo a 20 hombres, 5 mujeres y 7 niños ${ }^{12}$ procedentes de Caleta María, quienes quisieron voluntariamente regresar a Punta Arenas, por haber sido perjudicados con el movimiento sísmico del sábado.

En el Apostadero Naval se nos informó que el buque recorrió todos los puntos poblados de la ruta, tales como Puerto Yartou, La Paciencia, Puerto Harris, Caleta María y otros donde no ha habido novedad.

En Caleta María el patrullero dejó provisiones y medicamentos a los pobladores, que con el derrumbe habido perdieron gran cantidad de víveres.

Por último, el 4 de marzo de 1978 Hans Niemeyer Fernández (1921-2005) en su expedición que unió estancia Vicuña con bahía Yendegaia, siendo caleta María el campamento $\mathrm{N}^{\circ} 6$, escribió:

En el extremo sur de la extensa playa se levantan las construcciones de Caleta María: un galpón muy grande en ruinas, varias casas pequeñas y una más grande que es la que habita don Arturo Barrientos ${ }^{13}$. Estas construcciones formaban parte de la antigua estancia Almirantazgo ${ }^{14}$ y después, de las instalaciones del aserradero que por años mantuvo la firma Campos, Marcou y Cía. [...] Y 


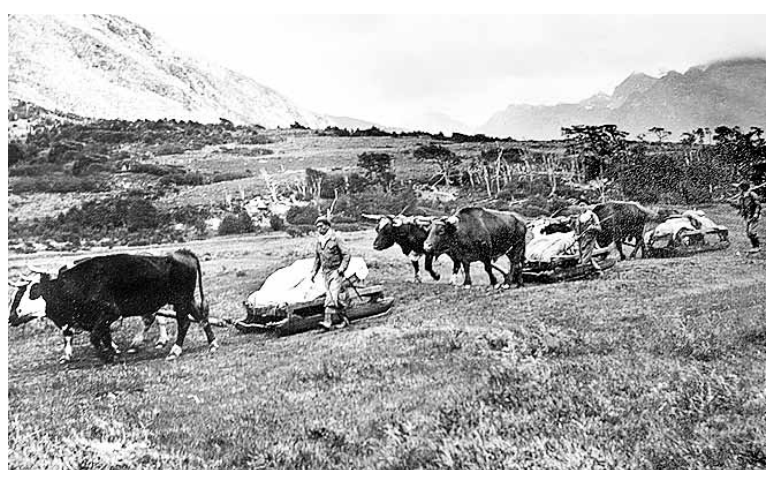

Fig.7. Transporte de cargas en el valle Azopardo (Fotografía de Lucio Genskowski P.).

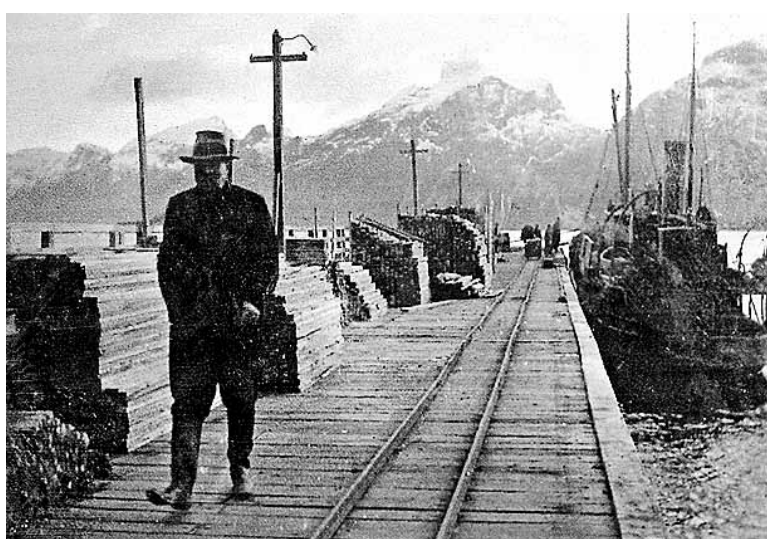

Fig.9. Alejo Marcou en el muelle de caleta María hacia 1946 (Fotografía de Lucio Genskowski P.).

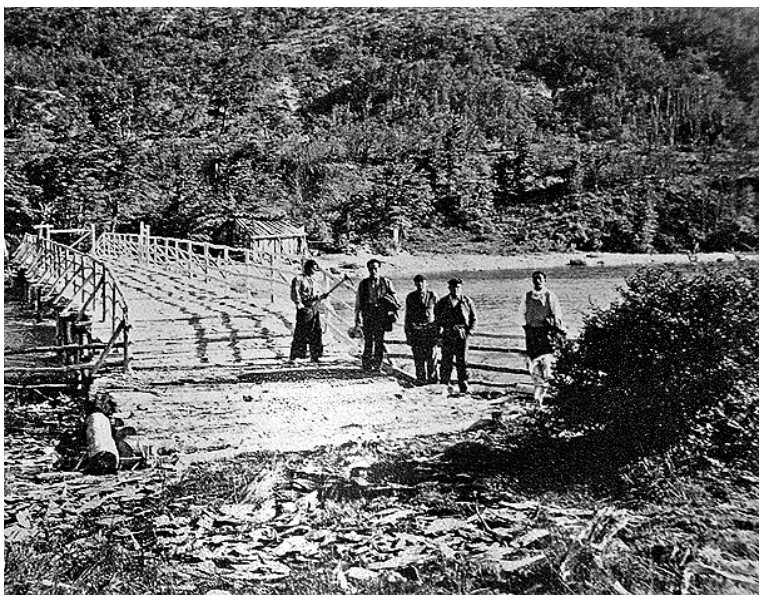

Fig.11. Puente construido a quince metros de la desembocadura del lago Fagnano y destruido tras el terremoto de 1949 (Fotografía de Lucio Genskowski P.).

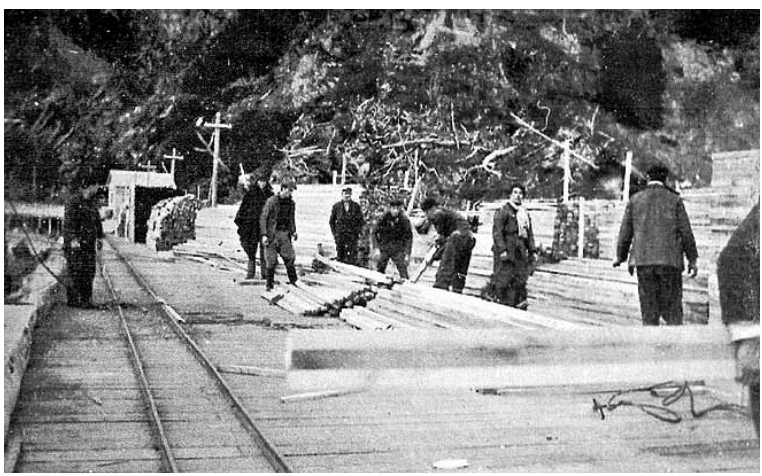

Fig.8. Trabajadores en el muelle de caleta María hacia 1946 (Fotografía de Lucio Genskowski P.).

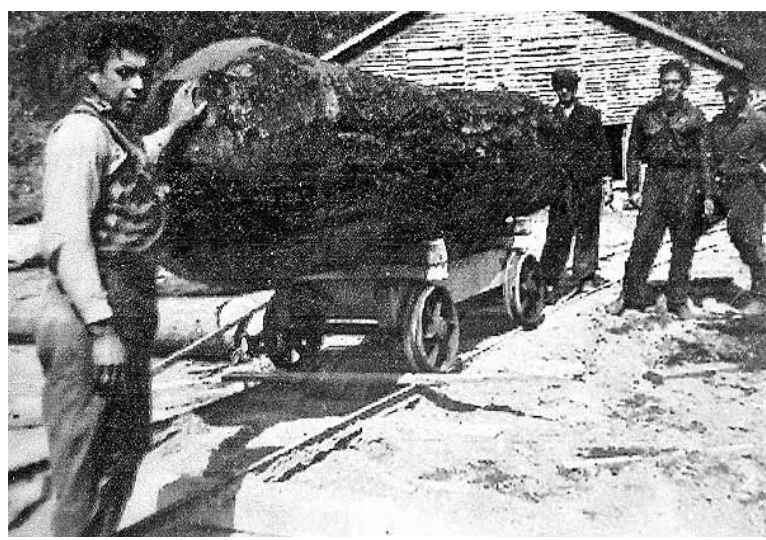

Fig.10. Trabajadores del aserradero caleta María (Fotografía de Lucio Genskowski P.).

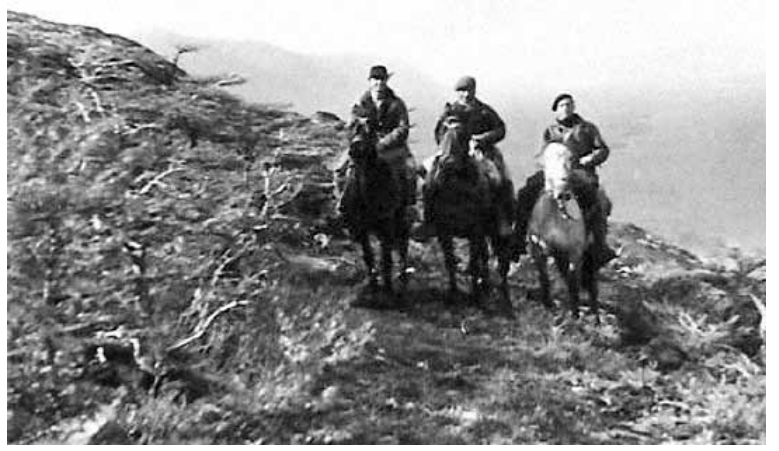

Fig.12. Jorge Campos, Raúl Arcos y Juan Kuzmanic, al fondo se aprecia el lago Fagnano (Fotografía de Juan Kuzmanic S.). 
en realidad, un grupo de casas algo arruinadas en el paisaje limpio y fresco del seno Almirantazgo era como haber vuelto un poco a la civilización ${ }^{15}$.

Los textos expuestos nos permiten visualizar tres momentos históricos de caleta María. En primer lugar, el inicio de una incipiente colonización, hecho registrado en 1913. Luego en 1949, con un poblado de trabajadores sustentado por la industria forestal y finalmente en 1978 cuando quedaban solamente vestigios del máximo desarrollo en cuanto a ocupación y explotación que ha presentado caleta María en su historia.

\section{CONSTRUCCIÓN ORAL DE LA HISTORIA DEL ASERRADERO CALETA MARÍA}

Germán Genskowski M. (Fig.42) quien se estableció hace veintiocho años en la orilla norte de la cuenca occidental del lago Fagnano, distante a 13 km de caleta María, aportó en el transcurso de la investigación datos relevantes del aserradero. Primero, al informarnos que su padre Lucio Genskowski Pietrogrande (1921-1977) tuvo relación directa con el aserradero y realizó un registro fotográfico de gran valor histórico. También nos informó sobre dos hombres, que al igual que su padre, tuvieron relación con el aserradero, ellos son Juan Kuzmanic Stanicic (1926) y Reinaldo Catalán Oporto (1927). Los testimonios de Kuzmanic y Catalán son de gran valor para el conocimiento de la historia del aserradero Caleta María, considerando que la información que se tiene sobre él es realmente escasa (Fig.43).

\section{Testimonio de Juan Kuzmanic Stanicic}

El aserradero Caleta María fue de quijotes. Con esta sucinta afirmación, Juan Kuzmanic Stanicic nos adentra en la historia del olvidado aserradero Caleta María. La afirmación de Kuzmanic no es producto de su imaginación o una ocurrencia automática e irreflexiva, él fue por más de dos décadas el contador general de la firma Campos Menéndez, propietaria del aserradero Caleta María.

Salía de la escuela a la una de la tarde y me iba corriendo hasta la oficina de los Campos Menéndez, que estaba ubicada en Colón 825, para cumplir mis ocho horas diarias de trabajo. A sus diecisiete años ingresó como junior a la firma Campos Menéndez, pero su perseverancia lo instaló dentro de poco tiempo en uno de los cargos de mayor responsabilidad de la destacada firma para la cual trabajó durante los años 1944-1969.

El aserradero Caleta María fue iniciado por la firma Campos Menéndez asociada con Alejo Segundo Marcou Belis (1887-1957) en 1942. La iniciativa del aserradero según Kuzmanic fue del viejo Marcou. Era un aserradero que no tenía mucho sentido y más se tenía porque los Campos Menéndez le tenían mucho aprecio a Marcou. Y así fue como Marcou tras insistir incansablemente logró convencer a la firma que era un buen negocio tener un aserradero en caleta María. Marcou era un tipo simpático, bonachón, macanudo, muy visionario, inteligente, bohemio y volátil [...] fue el que empezó con la búsqueda del petróleo en Magallanes [...] tenía mucha labia, se metía en cuanto proyecto había, siempre tenía ideas pero no tenia capital [...] siempre estaba en busca de alguien que lo financiara. Los terrenos de caleta María figuraba a su nombre (Alejo Marcou) pero la empresa Campos Menéndez era la que explotaba animales vacunos y el aserradero, Marcou arrendaba estos terrenos a la familia Campos ${ }^{16}$ afirma Kuzmanic. La firma Campos Menéndez era liderada por Francisco Campos Menéndez y su planta administrativa la conformaban por Placido Fernández, Benjamín Boric y Juan Kuzmanic.

Para el traslado de la madera proveniente del aserradero Caleta María la firma Campos Menéndez adquirió la goleta Gloria, con capacidad de carga para treinta dos mil pies de madera. Una vez llegada la carga a Punta Arenas, ésta era trasladada hasta el depósito de ventas que mantenía la firma ubicado en la intersección de las calles Chiloé con Monseñor Fagnano, donde se ubica actualmente el colegio San José. El encargado del local era un español que llegó de España, no recuerdo porqué llegó a Punta Arenas, pero el fue ha pedirle trabajo al viejo Campos, padre de los Campos Menéndez, y lo dejó encargado de la venta de madera, su nombre era Alfredo Fernández

\footnotetext{
${ }^{15}$ Niemeyer, 1978:5

${ }^{16}$ Así sucedió en la cuenca del lago Fagnano en jurisdicción nacional, en donde Pablo Dietert inicio la formación de la estancia Isabel hacia 1918. Durante la década siguiente dichos campos fueron transferidos a una compañía formado por Alejo Marcou, Ernesto Hobbs y otros, que imprimió un mayor vigor a las actividades de ganado mayor y menor, así como dio comienzo a la explotación forestal. (Martinic 2009:123).
} 
Martín, después la firma lo envió a Chile Chico.

En el año 1950 caleta María estaba poblada por unas cincuenta personas, todas ligadas al aserradero industrial e instalaciones complementarias, como el muelle, galpones, y casas.

A mí me tocaba frecuentemente viajar hasta Caleta María [...] eran viajes que se me hacían muy largos en la goleta de la firma, llamada Gloria, [...] esta goleta hizo numerosos viajes entre caleta María y la ciudad trayendo madera del aserradero, que vendíamos en Punta Arenas. Cuando viajábamos a caleta María era obligatorio pasar a isla Dawson a tomar desayuno con el administrador Mr Kenneth Morrison ${ }^{17}$ [...] el desayuno siempre terminaba con un buen vaso de Whisky, Morrison era muy simpático y amable, quien fue el padre de Mery y suegro de mi viejo condiscípulo Gastón Fuentes Río.

En una oportunidad, viajamos al lugar en la "Gloria" con don Jorge Campos Menéndez y su primo, Jorge de Grenade Campos (Fig.13), llegamos al lugar y al día siguiente nos dirigimos a caballo al lago Fagnano, que en pequeña escala pertenece a territorio chileno y en su mayor porción a Argentina. Cruzamos primero el río Azopardo con los caballos nadando (Fig. 14), río donde a una pequeña distancia hacia el mar había un grueso cable de lado a lado para sujetar las vigas que se cortaban a orillas del lago y se lanzaban al río para desde allí subirlas al aserradero [...], luego continuamos hacia el Lago acompañados por el administrador de aquel entonces, don Raúl Arcos Estay, quien nos indicó que soltáramos las riendas a los caballos y que ellos solos buscarían el camino y nos pasarían por los turbales allí existentes, como efectivamente sucedió. Uno pensaba, con cierto temor, si esos nobles animales no se equivocarían por casualidad. Siempre en subida llegamos al Fagnano, donde nos encontramos con el encargado de los vacunos, Pedro Martinic, quien en su modesto puesto nos invitó almuerzo. Luego salimos hacia el lugar donde se cortaban las vigas y luego, en la lancha, nos acercamos al lugar desde donde las precipitaban al río. Estábamos navegando tranquilamente en la lancha, "Susana" de nombre,

\footnotetext{
${ }^{17}$ Kenneth Morrison Mac Leod, falleció el 19 de julio de 1955. Su cuerpo yace sepultado en Puerto Harris, Isla Dawson. (Martinic 1995:29).

${ }^{18}$ Sucesor de Raúl Arcos Estay.

19 Toledo, 2010:76
}

cuando vemos que ésta estaba haciendo agua, así que muy apurados empezamos a sacarla con un balde y regresamos lo más pronto posible al puesto de Martinic. Salimos de regreso al aserradero, bajando esta vez no por la orilla del río si no por el cañadón Jackson, que salía al lado contrario a Caleta María, era un largo trecho, siempre con las riendas flojas de los caballos que conocían mejor que nosotros esos peligrosos parajes. Así llegamos a las casas, alojamos allí y al otro día regresamos a Punta Arenas sin novedad. Del viaje hicimos con Jorge Campos un detallado informe que enviamos a la oficina en Santiago y la de Buenos Aires.

Kuzmanic en sus breves estadías en caleta María tenía que verificar la cantidad de pies de madera elaborada por el personal del contratista Alfredo Agoni Solís (1904-1975), hacer inventarios, cancelar los sueldos al personal que trabajaba directamente para la firma Campos Menéndez, entre ellos a Domingo Fernández, administrador in situ del aserradero ${ }^{18}$, y a Pedro Martinic quien vivía en la orilla norte del lago Fagnano y era el encargado de la crianza de vacunos en aquel lugar. Antes nosotros (Sociedad Campos Menéndez) explotábamos los bosques malamente. En eso apareció Alfredo Agoni y nos pareció más conveniente contratarlo a él y pagarle por pie aserrado. Esto para nosotros era mejor que tener gente nuestra trabajando en caleta María. El viejo Agoni estuvo más o menos tres años trabajando con nosotros.

Finalmente el aserradero Caleta María, según Kuzmanic, llegó a su término en 1957, cuando Agoni concluyó sus trabajos como contratista para la firma Campos Menéndez, ese año coincidió con el fallecimiento de Alejo Marcou Belis ocurrido el 21 de marzo ${ }^{19}$. A Kuzmanic sólo le quedan recuerdos lejanos de la "locura" que significó el aserradero Caleta María: difícil accesibilidad y explotación de los bosques, aislamiento, rigurosidad del clima, inversión de grandes capitales y el esfuerzo enorme de hombres anónimos que hacha en mano derribaban los bosques. Ahora tu me dices que hay un camino que llega hasta caleta María, en aquellos tiempo cuando teníamos el aserradero te hubiesen tildado de loco por decir eso, si por mar era difícil llegar por tierra era imposible. Cuando se retiró Agoni, el contrato de arriendo de esas tierras con el Fisco estaba por vencer en unos pocos días, por lo que 


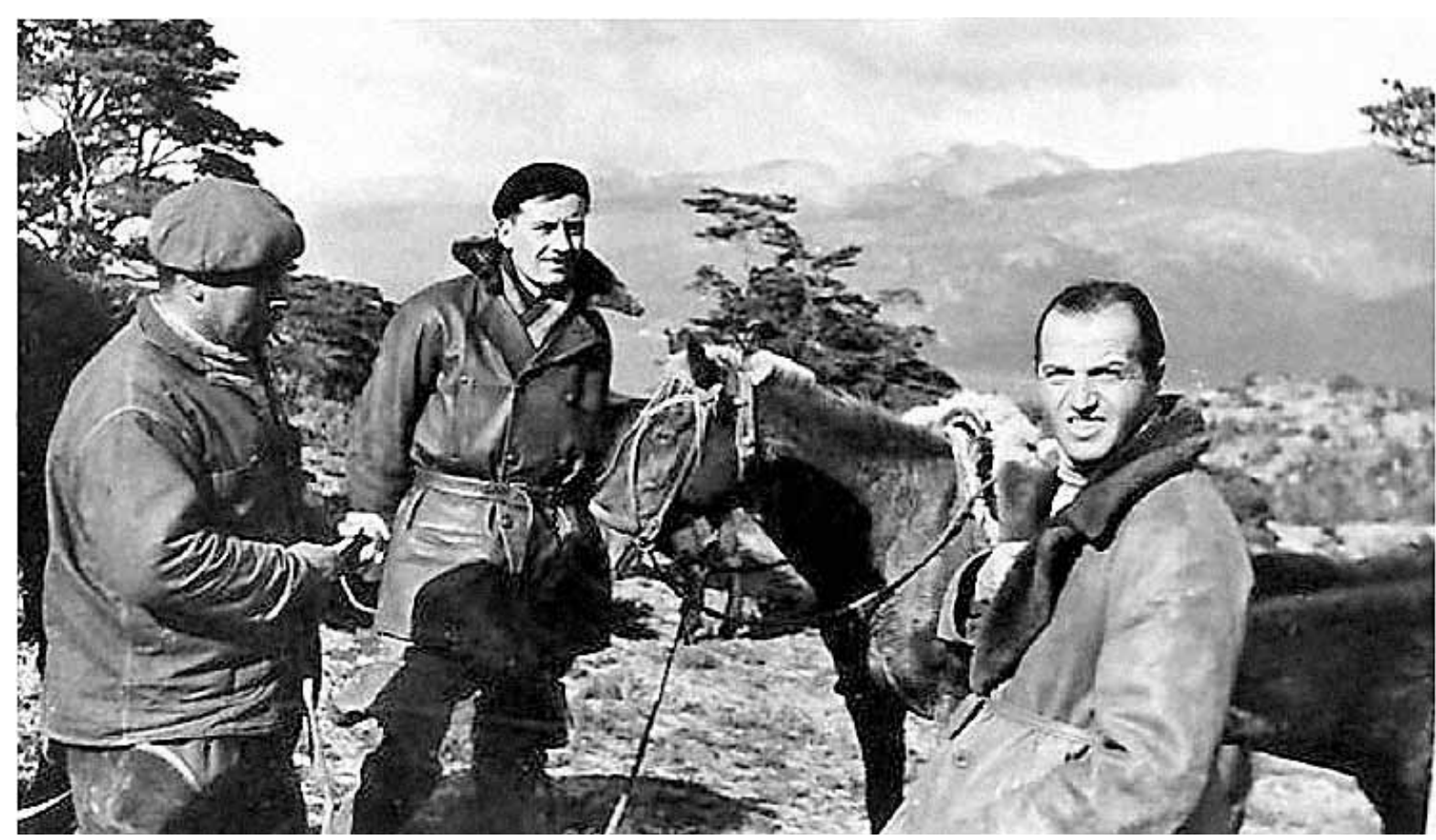

Fig.13. En el lago Fagnano, (de izq. a der.) Raúl Arcos Estay, Juan Kuzmanic y Jorge Campos Menéndez (Fotografía de Juan Kuzmanic S.).

se elevó a nivel superior entregar caleta María a un empleado de la sociedad, Lucio Genskowski Pietrogrande quien con tanta satisfacción se hizo cargo del establecimiento que tanto quería, Lucio era un enamorado de caleta María. ${ }^{20}$

Tiempo después supimos que Lucio estaba preso en la cárcel de Río Grande porque estaba cortando vigas en territorio argentino ${ }^{21}$ : como he dicho, el lago Fagnano pertenece en un 10\% a Chile y el resto a Argentina [...] no tengo idea acerca de cómo se sacó el problema de los hombros, pero tiempo después estaba nuevamente en el aserradero. Lo que no sé es si nosotros en su tiempo también pudimos haber extraído leña y madera de Argentina pues no hay ningún hito indicativo de los territorios.

\footnotetext{
${ }^{20}$ Según Germán Genskowski, su padre se habría vinculado con caleta María por medio de Alejo Marcou con quien trabajaba. ${ }^{21}$ Los árboles habrían sido talados por Gastón Agoni años anteriores a la llegada de Lucio Genskowski (ver más adelante). ${ }^{22}$ Luego de retirarse del aserradero caleta María en 1956, Catalán dejó Tierra del Fuego, en 1966 regresó a la isla donde habitó entre 1966-1980 al sur del lago Fagnano, en las inmediaciones de la desembocadura del río Betbeder, en 1980 se radicó en caleta María donde permaneció hasta el 2001. Ver García, 2012.
}

Tiempo después lamenté profundamente la muerte de este amigo que, repito, tanto quería, donde se dio vuelta trabajando: conducía un tractor que lo aplastó y mató instantáneamente. Mala, malísima muerte. Sus descendientes aún siguen exitosamente en el sector.

En caleta María la madera no era negocio, no era rentable, no era comercial, era muy difícil explotar los bosques allí, después había que traer la madera hasta Punta Arenas, era de quijotes y eso fue obra de Alejo Segundo Marcou Belis.

\section{Testimonio de Reinaldo Catalán Oporto}

Reinaldo Catalán, conocido como Don Cata, llegó por primera vez al aserradero Caleta María a fines de 1954 trabajando por dos meses directamente para la firma del aserradero y volvió en enero de 1955 trabajando, en aquella oportunidad, para el contratista, Alfredo Agoni Solís para el cual trabajó hasta abril de $1956^{22}$. La firma Campos le propuso a contrata a Agoni, quien tenía su aserradero en María Virginia, aserrar 4.000 vigas que estaban amontonadas en caleta María, pero 


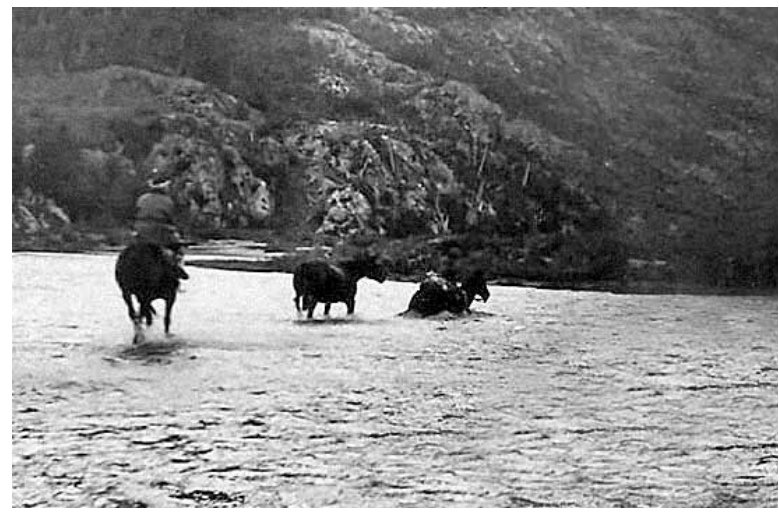

Fig.14. Cruzando el río Azopardo (Fotografía de Juan Kuzmanic S.).

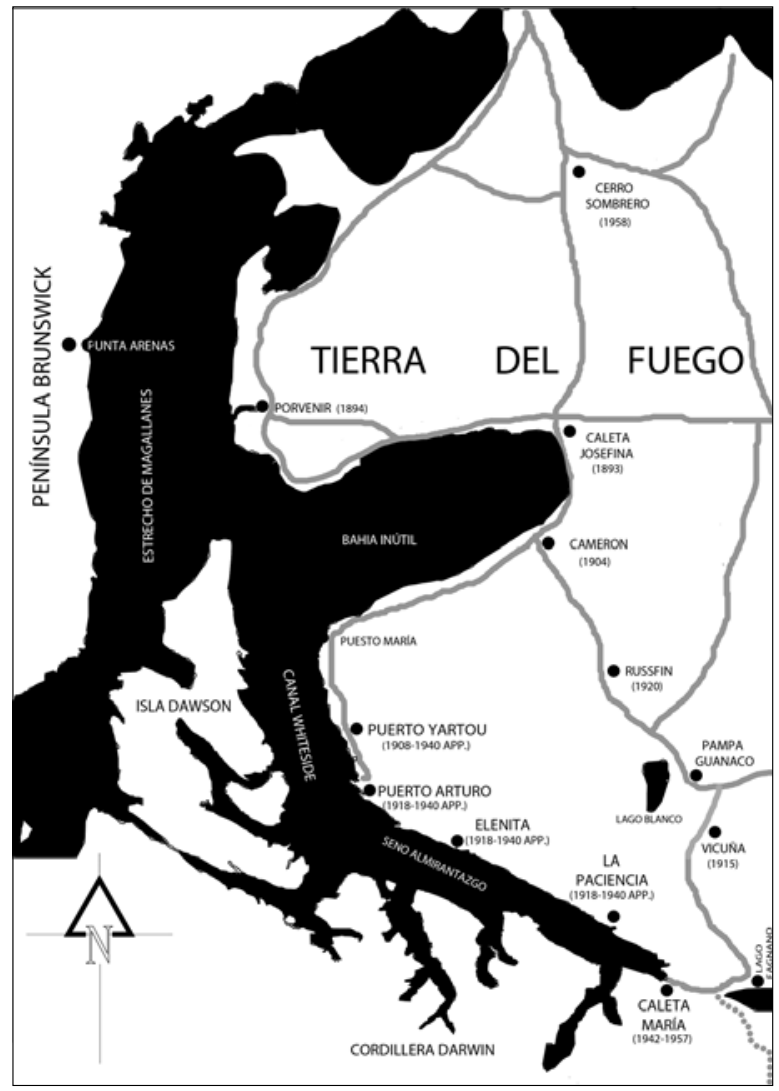

Fig.16. Mapa esquemático que muestra el emplazamiento de los aserraderos del fiordo Almirantazgo

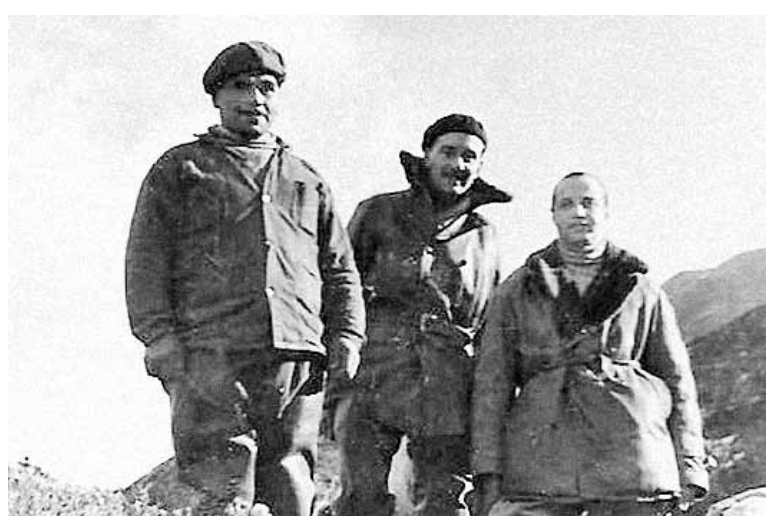

Fig.15. En caleta María (de izq. a der.), trabajador del aserradero Raúl Aros Estay, Juan Kuzmanic y Jorge Campos Menéndez (Fotografía de Juan Kuzmanic S.).

nosotros mandamos primero al palanquero del aserradero de Agoni a ver el estado de esas vigas y las halló buenas, así que Agoni aceptó. Con esta aceptación se dio inicio a los últimos años de vida del aserradero. Los costos e inversiones para mantener un aserradero en caleta María eran elevadas y no es arriesgado afirmar que no tuvo que haber sido tarea fácil explotar los bosques de esas latitudes, teniendo en consideración que los bosques que se talaban eran primordialmente los aledaños al lago Fagnano ${ }^{23}$. Era un trabajo lindo pero no era rentable para la firma (Campos Menéndez). Generaba mucho gasto. Imagínese, cortar la viga en el monte, de ahí había que tirarla hasta la orilla del lago Fagnano, luego había que hacer la balsa y llevarla hasta su desembocadura. De ahí desenganchar las vigas y tirarlas al río Azopardo que tiene más de $10 \mathrm{Km}$. de largo y todas las vigas no se iban hasta abajo, algunas quedaban en el camino. Cuando ya habían unas mil vigas, porque por menos no valía la pena, había que pasar a moverlas para que siguieran río abajo y eso se hacia con un botecito. A veces se movía una vigas y salían todas las que estaban amontonadas. Después había que remover las que quedaban atascadas en la red que estaba antes de la desembocadura del río. La red cruzaba el río de orilla a orilla y se ponía en diagonal. Era un cable de acero de dos pulgadas que sujetaba una hilera de troncos con un grampa, como el cable era pesado hundía la troncos para que las vigas

23 También se explotaban los bosques del valle Fontaine y alrededores. 
que venían por el río no pasaran por debajo, por eso se prefería talar lenga y no coigüe, porque la lenga es mas liviana y casi la mitad del tronco queda sobre el agua, en cambio el coigüe es muy pesado en el agua y hubiese pasado por debajo de la red. La red aguantaba mil vigas. Las vigas quedaban detenidas en la red y la que venia atrás arrastrada por la corriente golpeaba a la viga por detrás y la iba empujando hacia delante y quedaban al lado de la orilla, era un trabajo precioso. Cuando subía la marea, como el cable no estaba tensionado, la marea hacia un efecto bolsón con la red y dejaba toda las vigas en la orilla. Después con bueyes había que llevarlas hasta el aserradero, elaborarlas y ponerlas en el muelle para que el barco se las llevara a Punta Arenas. Yo me preguntaba ipara que tener un aserradero tan lejos, tanto sacrificio, tanto gasto, si en Punta Arenas habían aserraderos más cerca y que vendían la madera más barata? A este relato hay que agregarle al peligro constante al que se exponían los trabajadores y las inclemencias del clima propias del lugar.

Las faenas en caleta María empezaban antes que saliera el primer indicio de luz natural. Los trabajadores a primera hora se ubicaban en sus puestos de trabajo, unos en el aserradero y otros en el lago Fagnano para cortar y balsear la vigas. Con Agoni trabajábamos tempranito, a las 6:30 estábamos listos para trabajar. A los que trabajábamos con contrato como a las 5:30 pasaba golpeando las puertas de las piezas y decía iya chicos vamos levantándonos! Eso en verano, en invierno se hacia otras cosas, porque el agua escarchaba y no se podía transportar las vigas por el río. Agoni era muy jodido y exigente, a mi me advirtieron que llevara bien mis cuentas, por qué si Agoni tenía algo para arrollarte, te lo arrollaba (...) una vez me estafó y me retiré.

Si las faenas en caleta María empezaban a primera hora, estas terminaban cuando la luz del día había pasado a ser un mero recuerdo. En caleta María trabajábamos hasta tarde, oscuro, porque después de aserrar había que arrumar toda la madera. Cintas, piquetes, tablas. Había un tractorcito que llevaba la toda la madera hasta el muelle y cuando llegaba la barcaza habían carritos especiales, se les ponía harta madera encima y entre dos personas los deslizaban por los rieles que tenía el muelle, se deslizaban fácil porque nosotros aceitábamos bien las ruedas. Casi al final del muelle había un quiebre y ahí habían paredes porque cuando había viento podía dar vuelta los carritos.

Con respecto a la forma de pago de los trabajadores, estos tenían dos opciones de sueldo; los que querían trabajar por pies o por pulgadas, entonces el que trabajaba en monte grueso le convenía trabajar por pie, si era en monte delgado le convenía trabajar por pulgada. Uno era el que elegía. La firma del aserradero llevó a cabo una explotación mixta, forestal y ganadera en el sector del lago Fagnano, La firma también llevó vacunos para el lago Fagnano, pero los cercos se rompieron y los animales se fueron para la Argentina y se pusieron baguales, ahí trabajaban los bagualeros Pérez, Hueicha y Carrasco que vivía con su esposa en un rancho al lado del lago Fagnano. Cada 15 días carneaban un vacuno y lo llevaban a caleta María para el consumo del personal.

Reinaldo Catalán afirma que caleta María era un pueblito y la mayoría de sus pobladores era gente amable y trabajadora proveniente de Chiloé, gente que superaba en promedio los treinta años de edad. En el año de su llegada, en 1954, habían más de cuarenta pobladores viviendo en ella, pero según Catalán a mediados de la década del cuarenta habían más de 100 personas entre caleta María, lago Fagnano y el valle Jackson, todas ligadas a la actividad maderera. Cuando llegué a caleta María habían más de quince ranchos con seis literas cada uno. Ahí nos preparábamos el almuerzo, los ranchos tenían baños pero no duchas así que nos bañábamos en bañeras, cada uno calentaba su agua, luz eléctrica no había, usábamos pura vela para alumbrar. Cuando queríamos comprar víveres, los comprábamos en el almacén que tenía la firma en la casa de la administración del aserradero, que estaba a cargo de don Domingo Fernández. Antes había un almacén en el mismo muelle de embarque pero con el terremoto del cuarenta y nueve desapareció, el cerro se vino abajo y lo destruyó todo, ahí vivía un matrimonio joven y por suerte el día antes del terremoto se habían cambiado de rancho, si no los mata. A nosotros nos iba a buscar un barco cuando terminaba la temporada. A veces estábamos hasta seis meses sin ver embarcación de ningún tipo. La casa de la administración estaba llena de papeles y documentos amontonados, estaban 
las liquidaciones de los hombres que trabajaban en caleta, habían repisas llenas de documentos, lástima que nunca se me ocurrió guardar algo, porque todos esos papeles después se perdieron o los quemaron.

\section{El naufragio de la "Gloria"}

Hecho desconocido en la historia de los naufragios fueguinos fue el siniestro de la goleta Gloria ocurrido en el fiordo Almirantazgo el 2 de junio de 1955. Como hemos mencionado, esta embarcación perteneciente a la firma Campos Menéndez era utilizada para el traslado de la madera elaborada desde el aserradero Caleta María a la ciudad de Punta Arenas. Entre sus tripulantes y pasajeros estaban Reinaldo Catalán Oporto, Pedro Barrientos, Alfredo Agoni Solis, Juan Kuzmanic Stanicic, Heriberto Yañez (maquinista), Antonio Délano (capitán).

Eran aproximadamente las 15:00 hrs., la "Gloria" con el motor rugiendo se alistaba para tomar rumbo a Punta Arenas. La gente que quedaba en caleta María se despedía desde el muelle de los que se marchaban a Punta Arenas, algunos se volverían haber pronto, quizás la próxima temporada, otros nunca más. La bahía Azopardo estaba escarchada más de trescientos metros mar adentro. El viento estaba ausente, el mar en completo sosiego, parecía un día perfecto para navegar.

Respecto a este incidente Juan Kuzmanic anotó en sus memorias de vida:

Era un día muy helado del mes de junio, calculo del año 1955, llegamos a tiempo a Caleta María, donde en esa época estaba de administrador Domingo Fernández Pérez, español, hermano de mi entonces jefe, Plácido Fernández, con su mujer, la señora Pura. Fui muy bien recibido y atendido, como era habitual por parte del matrimonio, yo siempre llevaba a Domingo las revistas y novelas de pistoleros que compraba y leía, porque él también era un ávido lector; como anécdota puedo contar que se hizo un cajón de madera alargado, del tamaño de las novelas, allí las guardaba y leía en el orden en que se encontraban y, cuando terminaba la hilera, volvía a leer la primera de la fila y así seguía hasta que yo llegaba con más ejemplares. Domingo falleció muy pronto de un cáncer al estómago, dejó a doña Pura y a su hija
Luisa, ciega de nacimiento (...) .

Estuve dos días en Caleta María cumpliendo mi cometido, al cabo de los cuales ya nos preparamos para retornar a la ciudad base, Punta Arenas, cargados de madera y tambores de petróleo vacíos. Nos despedimos y abordamos la goleta veintitrés personas, entre el personal de Agoni, incluidas dos mujeres, la tripulación y yo, zarpamos tipo 15:00 horas. Estábamos todos debidamente acomodados a bordo para el viaje, yo como tenía camarote estaba en el puente con el capitán, cuando sube corriendo el maquinista, Heriberto Yañez, a decir que estaba entrando agua a la sala de máquinas. Bajamos de inmediato con el capitán y el agua ya llegaba casi a la mitad del motor (...) Délano ordenó bajar los botes y una chata que se usaba para acarrear leña y ponerse salvavidas. Cuando yo abandoné la nave el agua ya había casi detenido al motor, producía un ruido que daba más susto aún. Lógicamente que el primero en subirse a un bote fui yo, que gritaba las mujeres y los niños primero, claro, eso es lo que se dice como frase de costumbre, pero cuando uno ve que su vida es la que corre peligro, la frase que te viene a la cabeza es "sálvese quien pueda" no más.

Un muchacho del personal de Agoni, aterrorizado por lo rápido que subía el agua dentro de la goleta, se tiró de cabeza al agua y por suerte sus compañeros lo sacaron de inmediato antes de que se congelara porque, como he dicho, estábamos en Junio, con un frío terrible y ya oscureciendo. Todos abandonamos la goleta "Gloria" y los marinos remaban hacia una pequeña isla llamada "Tres Mogotes", ya era de noche y la isla estaba cubierta de nieve y escarcha.

Logramos hacer fuego con unas peinetas de carey que portaba una de las mujeres del grupo y así estuvimos toda la noche dándonos vuelta y vuelta alrededor de la exigua fogata. ¡Qué noche más helada, larga y preocupante! Cuando por fin amaneció y ya se vio un poco de luz, comprobamos que nuestra embarcación estaba ahí. No se había hundido pero el agua llegaba hasta la mitad del puente de mando. Con el capitán en uno de los botes fuimos al aserradero donde don Domingo nos miraba con tamaños ojos, asombrado inquiriendo qué nos había sucedido. Le contamos todo lo acontecido y luego con una lancha a motor se transportó al personal de regreso a sus casas 


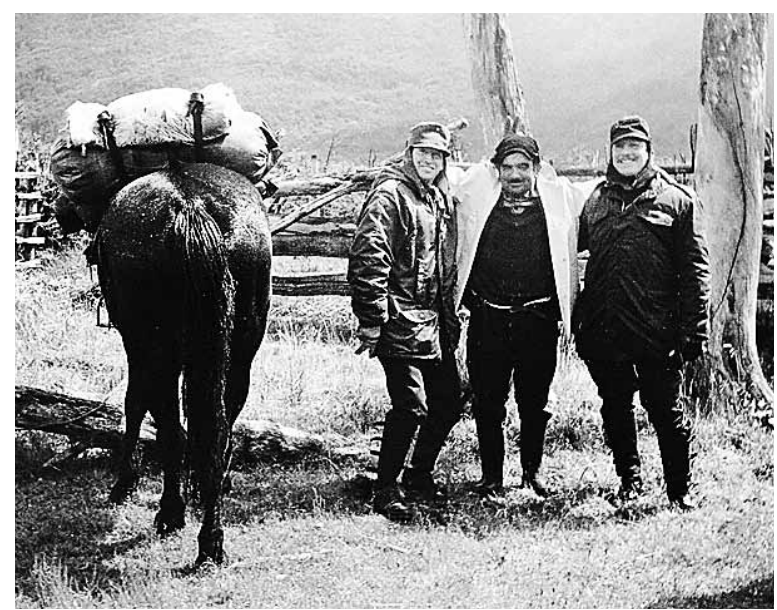

Fig.17. De izq. a der. Sargento de carabineros Luís Elgueta, Reinaldo Catalán y el carabinero Olivera. Valle Betbeder, 1987, luego de una expedición a Yendegaia (Fotografía gentileza de Reinaldo Catalán)

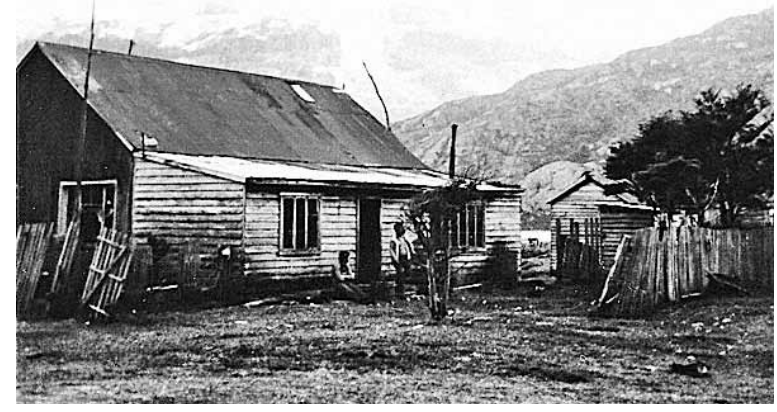

Fig.19. Caleta María, 1985 (Fotografía gentileza de Reinaldo Catalán).

para finalmente ir a rescatar a nuestra goleta, la "Gloria". La remolcamos hasta cerca de la playa y de ahí por medio de un cabrestante la subimos lo más arriba posible en la arena de la playa ubicada al final del seno Almirantazgo. A medida que la subíamos salía agua por todos lados: se impregnó todo de agua salada: motor, radio, camas, etc., así pudimos luego comprobar que cuando zarpamos rompimos una parte de la proa con el hielo que había en el agua, hielo que se explica porque el agua no era totalmente salada (el agua de mar no se congela) ya que en su cercanía estaba la desembocadura del río Azopardo.

Sigo con mi relato, el pedazo de madera que se rompió con la escarcha era de unos $25 \mathrm{cms}$. de largo por $5 \mathrm{cms}$. de ancho y este pequeño orificio bastó para que en un par de horas la embarcación

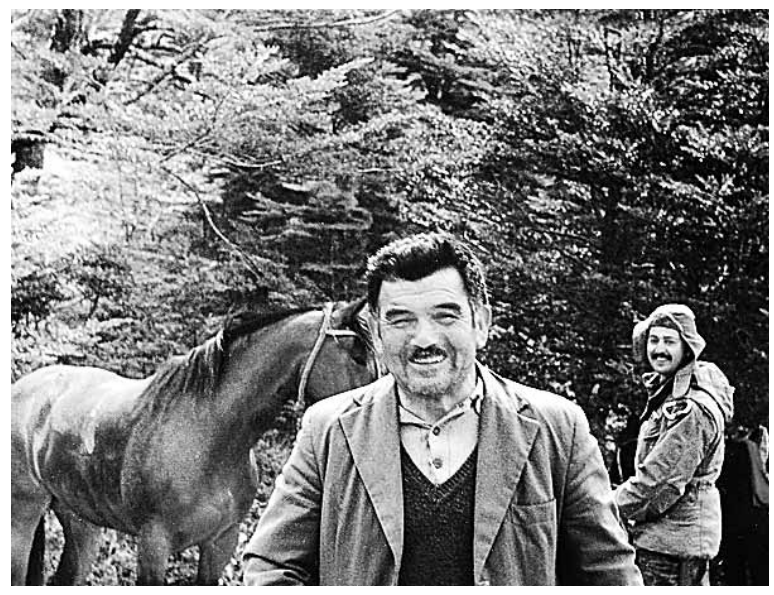

Fig.18. Reinaldo Catalán, caleta María 1985

(Fotografía gentileza de Reinaldo Catalán).

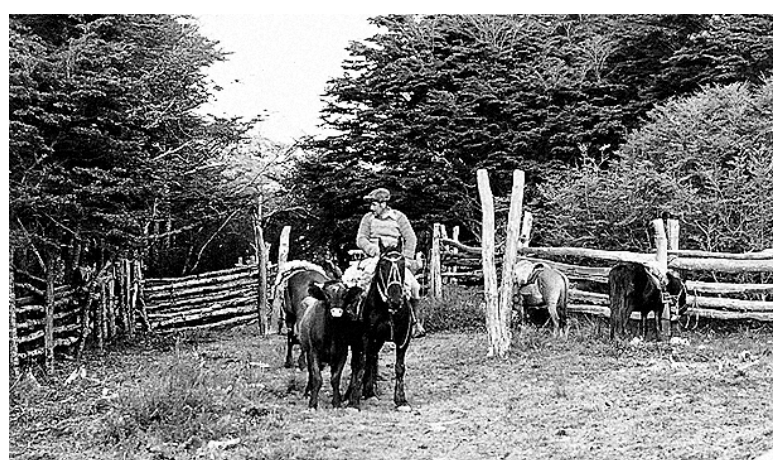

Fig.20. Reinaldo Catalán en faena ganadera (Fotografía gentileza de Reinaldo Catalán).

estuviera bajo el agua. Allí en Caleta María estábamos bien, en tierra, en casa y con las comodidades mínimas del caso. Así pues dí la orden que todos los días, las dos veces de rigor, con la radio del aserradero el capitán hablara a la Gobernación Marítima y manifestara "Goleta Gloria, fondeada en Caleta María y sin novedad". Continuamos así por veintiún días hasta que nosotros, es decir la tripulación de la "Gloria" más el personal del contratista Agoni arreglamos el motor, las ropas, la perforación de proa, la radio, etc., y así llegó el momento en que nuestra averiada goleta estuvo a punto de zarpar nuevamente.

En Punta Arenas, en la oficina, y en mi casa, no se preocupaban, sabían que yo estaba allá y Teresa pensaba que Domingo y Pura me estaban regaloneando como siempre pues me estimaban de 


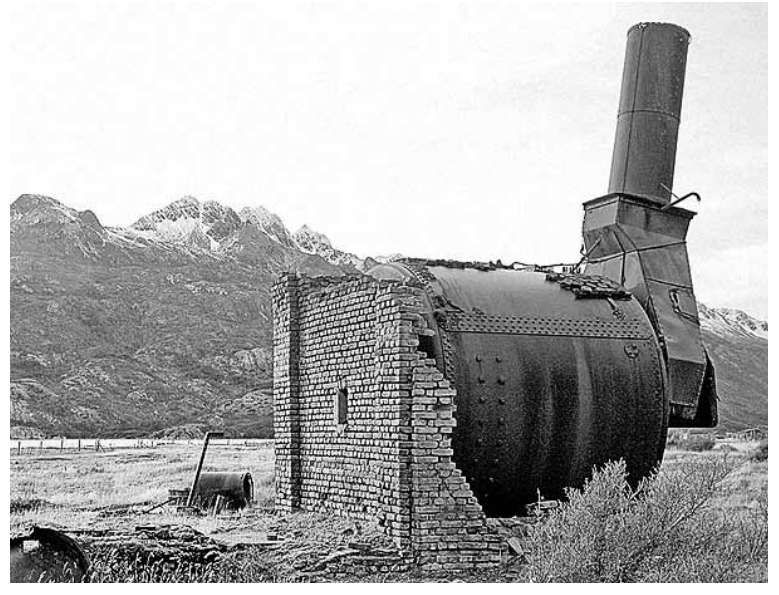

Fig.21. Vestigio de la caldera del aserradero Caleta María, 2005.

verdad, pero cuando empezaron las llamadas diarias de Santiago y de Buenos Aires preguntando por mí, cada vez con más insistencia, todos empezaron a inquietarse, máxime si lo único que sabían era el reporte diario aquél de "Goleta Gloria, fondeada en Caleta María, sin novedad".

Una vez reparado todo lo mejor posible, botamos la goleta al agua, hicimos andar el motor que quedó, según nos pareció, muy bien, dimos unas vueltas por la bahía y decidimos zarpar al día siguiente bien temprano, lo que hicimos luego de despedirnos y agradecer una vez más tanta hospitalidad y ayuda. No estábamos del todo tranquilos ya que el famoso agujero lo habíamos tapado con un pedazo de tabla con brea, como mejor quedó. En definitiva, llegamos a Punta Arenas, sin novedad y con mucha felicidad, allí premié a la tripulación, de capitán a paje, con una buena cantidad de dinero, por su buen comportamiento y por su importante labor extra debido al percance ya detallado, que pudo haber terminado en una gran tragedia.

Luego hice una carta larga y explicativa, bien detallada, respecto de lo sucedido, a las oficinas de Santiago y de Buenos Aires y de vuelta recibí numerosas felicitaciones, incluso de don Francisco Campos Torreblanca.

Comprendo al escribir estas letras que la narración de lo sucedido no produce mayor intranquilidad ni sobresalto, pero para poder entender plenamente la magnitud de lo ocurrido y de lo que pudo haber ocurrido y no ocurrió, habría que haber

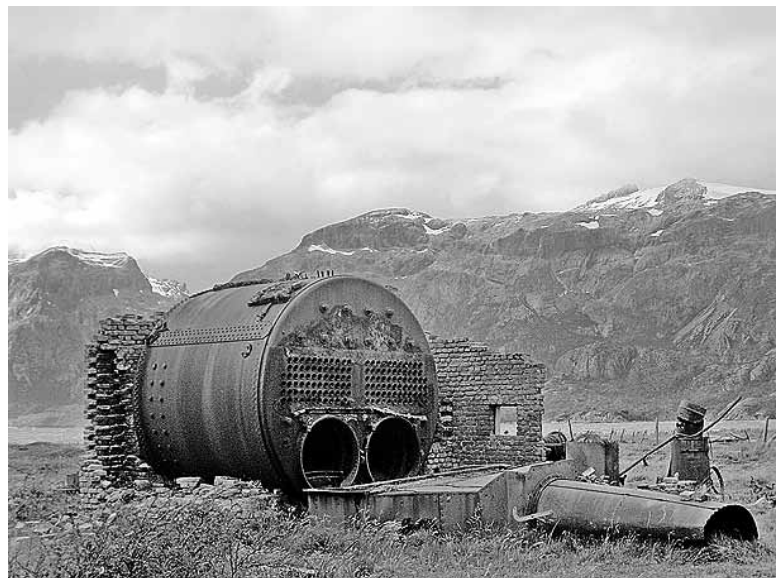

Fig.22. Vestigio de la caldera del aserradero Caleta María (Fotografía del autor, 2013).

estado "in situ" y vivirlo, para así darse cuenta del pánico inicial, el susto constante, el frío gélido en la mitad de la nada, sin saber con certeza si sería posible un rescate y hasta sobrevivir.

Lo sucedido quedó en completo hermetismo entre los protagonistas, en Punta Arenas las autoridades no se podían enterar, si el hecho adquiría connotación pública la firma del aserradero se exponía a serias sanciones por no haberse tomado las medidas de seguridad antes de zarpar. La firma Campos Menéndez, tal como lo había prometido, gratificó económicamente a todos los tripulantes de la goleta por haber guardado silencio de lo sucedido y por no haber permitido que la "Gloria" terminara en el fondo del mar. Años más tarde el casco de la "Gloria" terminó abandonada en bahía Buena $^{24}$. Juan Kuzmanic conserva como un tesoro personal la placa con el nombre de la que un día fue la embarcación del último de los grandes aserraderos del fiordo Almirantazgo, la "Gloria".

\section{LOS HABITANTES DE CALETA MARÍA DESPUÉS DEL ASERRADERO}

Si bien el objetivo del artículo es el rescate de los antecedentes históricos del aserradero Caleta María nos parece pertinente referirnos a las personas que habitaron la caleta con posterioridad al cierre del aserradero, esto con el objetivo de complementar y aportar a la escasa documentación existente respecto

\footnotetext{
${ }^{24}$ Sector Fuertes Bulnes.
} 


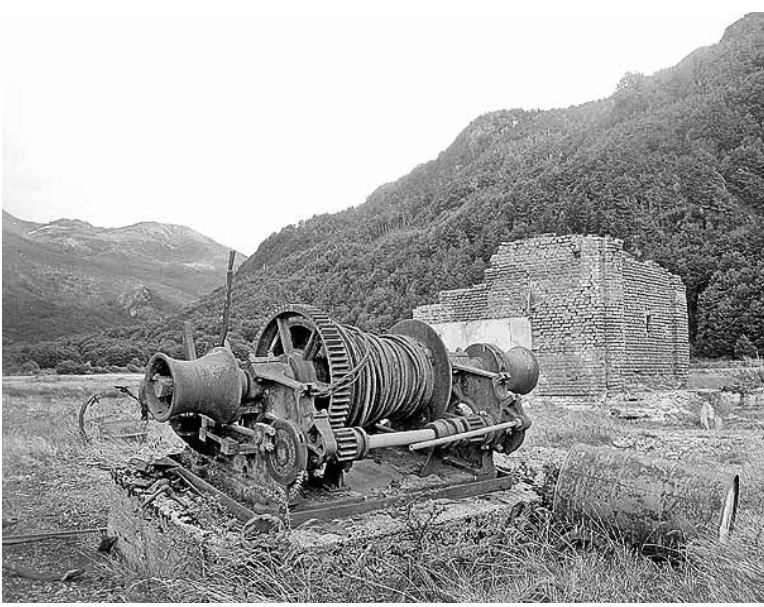

Fig.23. Steam Winch de la firma Clarke, Chapman Company, Gateshead, England (Fotografía del autor, caleta Maria, 2013).

al área de estudio.

\section{Lucio Genskowski Pietrogrande}

La primera persona en establecerse en caleta María luego del cierre del aserradero fue Lucio Genskowski Pietrogrande (1921-1977) y sus trabajadores. Si bien no conocemos la fecha exacta en que se estableció en caleta María e inició por su cuenta propia la explotación ganadera y forestal, esta fue a comienzos de la década de 1960 y se prolongó hasta 1973. Entre los trabajadores de Genskowski estaban sus hijos Rodrigo y Germán, Francisco Oyarzún, Dariego Nain Coyopai, Luís "Macheteado" Muñoz, Andrade "El pata de oveja", los hermanos Arturo, José, Raúl y Teófilo Vidal Barrientos, "Pecho de Toro", los "Bandurrias", un tal Álvarez y Jorge Muñoz ${ }^{25}$, la mayoría hombres proveniente de la isla de Chiloé. Principalmente durante el verano y en tiempo de vacaciones la señora de Lucio Genkoswski, Yolanda Middleton Acuña se trasladaba hasta caleta María junto a sus hijos menores Adrián y Lucio.

La explotación de los bosques por parte de Lucio Genskowski se concentró en el valle Fontaine, la ribera norte occidental del lago Fagnano y en los terrenos próximos al límite internacional con Argentina. Estos eran los bosques que no habían alcanzado a ser explotados por el personal del aserradero Caleta María.

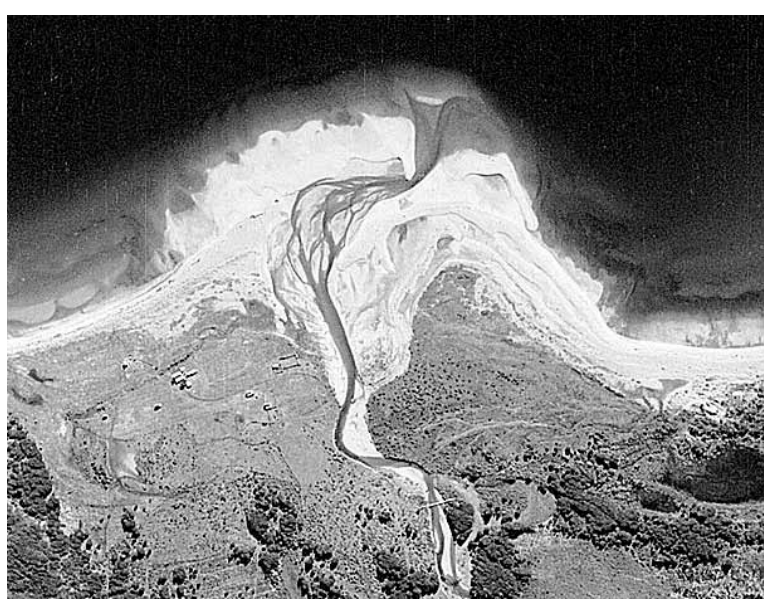

Fig.24. Fotografía aérea de Caleta María hacia el 2000. Se aprecia el puente sobre el río

Fontaine construido por Alejandro Concha y la colaboración de Reinaldo Catalán en 1994.

\section{Un tractor al lago Fagnano}

No fue cosa fácil para Genskowrki y sus trabajadores explotar los bosques aún disponibles, la existencia de grandes capitales para la explotación maderera ya era parte del pasado. Para iniciar sus trabajos Lucio Genskowski tuvo que hacer reparaciones en el muelle de caleta María, planchados y puentes, además de introducir un tractor, marca David Brown (Fig.45), que fue trasladado desde caleta María hasta el lago Fagnano, todo un desafío considerando la difícil accesibilidad y accidentada geografía que tuvieron que enfrentar el empresario y sus trabajadores para poder trasladar el tractor hasta el destino mencionado. Según Francisco Oyarzún, y Reinaldo Catalán ${ }^{26}$ el tractor trajo consigo muy malos ratos debido a los accidentes que ocasionó en especial a Lucio. El primer accidente significativo ocurrió hacia 1967, cuando por primera vez el tractor fue desembarcado en el muelle de caleta María, que por el mal estado de su estructura cedió, cayendo el tractor con Lucio Genskowski, quien lo manejaba, a las aguas del fiordo Almirantazgo. De este incidente, pese al peligro, Lucio logró salir con

${ }^{25}$ Jorge Muñoz vivía en caleta María junto a su madre (de 80 años de edad) y esposa Olfa Ojeda y era el trabajador de mayor confianza de Lucio Genskowski.

${ }^{26}$ Entre 1966 y 1980 Catalán se estableció en la orilla sur del lago Fagnano para trabajar en la crianza de vacunos (García 2012:66), convirtiéndose en el único vecino de Lucio Genskowski. 
vida, más tarde el tractor sería sacado del agua tirado por una yunta de bueyes hacía la orilla. El segundo accidente significativo ocurrió a mediados de 1967 en el lago Fagnano, cuando por alguna circunstancia el tractor se dio vuelta y aplastó a Lucio, después de mucho esfuerzo sus trabajadores lograron liberarlo, el accidente lesionó gravemente su columna vertebral. Al comienzo las molestias no existían pero al cuarto día se empezaron a ser presentes y cada vez más graves. Germán Genskowski junto a Dariego Nain tuvieron que dirigirse hacía el retén de Vicuña para pedir ayuda. Por medio de un familiar consiguieron que un avión de la línea Davison fuera a evacuar a Lucio, sin embargo el avión estaba autorizado para que aterrizara en la pista de Pampa Guanaco (a 80 km , aproximadamente, del lugar del accidente), pero el piloto desobedeciendo las ordenes aterrizó en la remota pista de caleta María, que era lo lógico. Lucio Genskowski fue transportado por el lago Fagnano por medio de una balsa hasta su desembocadura, desde allí, en camilla y en una lancha fue llevado hasta caleta María para poder abordar el avión. Germán recuerda la odisea que significó evacuar a su padre desde el lago Fagnano y que luego éste regresó al mismo lugar y ahí andaba en su tractor y con yeso manejando, porque le enyesaron el tronco entero, También recuerda que por suerte ese día en que cayó el tractor la cabina no estaba puesta porque ahí si que se hubiese ahogado.

Luego que Lucio Genskowski se retiró de caleta María hacía 1973, el tractor David Brown, quedó abandonado por alrededor de 17 años hasta que sus hijos Germán y Rodrigo lograron ponerlo nuevamente en funcionamiento. En la actualidad este tractor es utilizado por Germán Genskowski en su estancia Lago Fagnano. Reinaldo Catalán recuerda que el tractor en los años que permaneció abandonado cerca del límite con Argentina se había convertido en una especie de atractivo turístico, ya que las personas que visitaban la zona, preferentemente militares, no podían creer que hubiese un tractor en aquel lugar y esto los motivaba para ir hasta el sitio donde se encontraba.

\section{Lucio Genskowski es detenido en el lago Fagnano}

El 12 de abril de $1966^{27}$ ocurrió un suceso engorroso en el cual Lucio Genskowski resultó detenido por gendarmes argentinos. Según la información

\footnotetext{
${ }^{27}$ Dato proporcionado por Reinaldo Catalán.
}

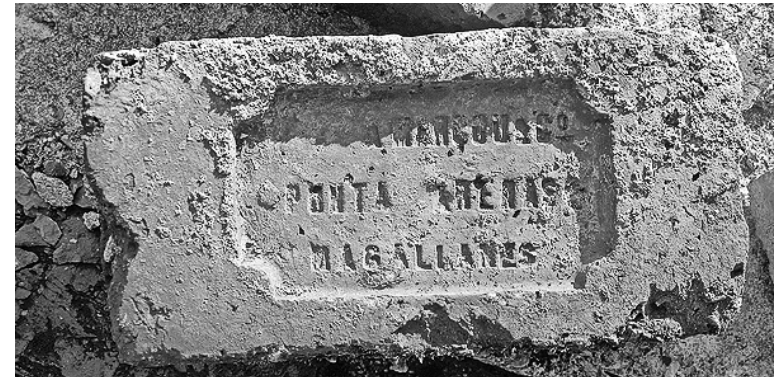

Fig.25. Ladrillo de la industría Marcou y compañía (Fotografía del autor, caleta Maria 2013).

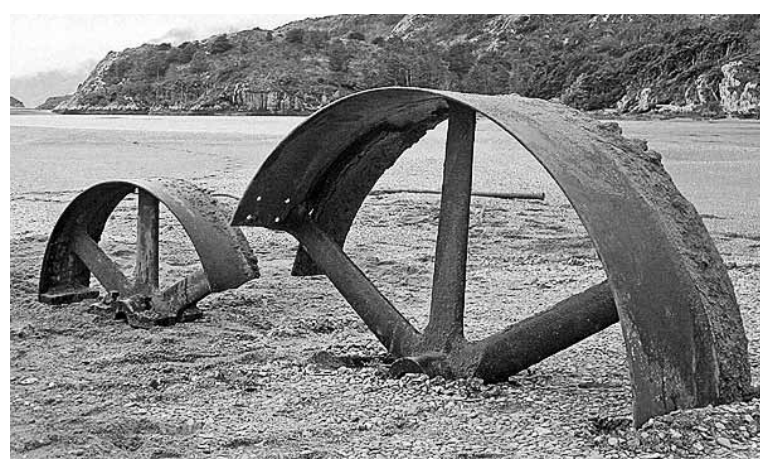

Fig.26. Ruedas de un locomóvil a orillas del río Azopardo (Fotografía del autor, caleta María 2013).

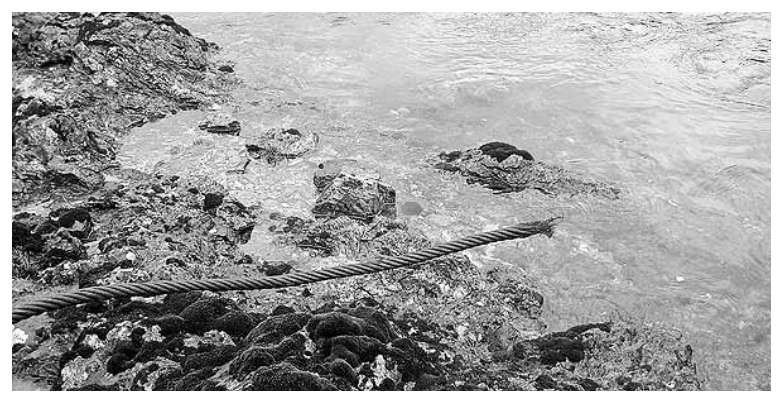

Fig.27. Vestigio de un cable de acero, ingresando al río Azopardo, utilizado para la detención de las vigas (Fotografía del autor, noviembre 2011).

entregada por trabajadores sus Francisco Oyarzún y Arturo Vidal como también por Reinaldo Catalán, mientras se desarrollaban faenas de tala en las cercanías del límite con Argentina unos animales habían cruzado la frontera, al ir Lucio Genskowski tras ellos junto a un trabajador de apellido Álvarez y Dariego Naín Coyopai fueron sorprendidos por gendarmes los cuales detuvieron a Lucio y a Álvarez, el que aprovechando un descuido de los vigilantes logró escapar. Por este acto Lucio fue agredido por los gendarmes. El motivo 
de la detención se debía a que los gendarmes acusaban a Lucio de tala ilegal de árboles, sin embargo el que había talado los árboles en territorio argentino habría sido Gastón Agoni, hijo de Alfredo Agoni Solís, quien había trabajado como contratista para el aserradero Caleta María a mediados de la década de 1950.

Ocurrida la detención y enterado de esto el resto de los trabajadores, Jorge Muñoz fue avisar a Reinado Catalán quien vivía en la orilla sur del lago Fagnano y conocía la ruta desde aquel lugar hasta el retén de carabineros ubicado en las cercanías de la estancia Vicuña, lugar donde podían pedir ayuda. Reinaldo Catalán recuerda que cuando Jorge Muñoz llegó a su rancho miraba hacía el lugar donde habían detenido a Lucio Genskowski y con los ojos sollozos decía cómo estará mi patroncito. Así Reinaldo Catalán, Francisco Oyarzún y Dariego Naín, testigo presencial del suceso, tomaron rumbo hacia el retén de Vicuña donde dejaron constancia de lo acontecido. Quince días después de realizada la denuncia llegó hasta caleta María, en una embarcación de Carabineros de Chile de Porvenir, Germán Genskowski quien junto a carabineros se dirigió hasta el lugar de la detención, allí los gendarmes argentinos les informaron que Lucio había sido llevado detenido hasta la ciudad de Río Grande (Tierra del Fuego, Argentina), pero que había emanado una orden de liberarlo y trasladarlo al lugar donde había sido detenido. Germán Genskowski recuerda de este encuentro entre los gendarmes argentinos y carabineros de Chile, que estos últimos antes de presentarse ante los gendarmes, se lustraron las botas, se ordenaron las chaquetas y gorras, algo que contrastaba con la presentación descuidada de los gendarmes argentinos.

\section{Nacimiento de una niña en caleta María}

Entre los sucesos ocurridos en caleta María, cabe mencionar el nacimiento de la hija del trabajador Arturo Vidal en 1972. El parto se adelantó a la fecha pronosticada y tuvo que ser asistido por Arturo Vidal y Reinaldo Catalán, naciendo el bebé sin problemas. En este tiempo los víveres escaseaban en caleta María, don

28 Veinticinco años después, en 1985, Germán Genskowski volvería nuevamente al lago Fagnano, donde poco a poco y con mucho esfuerzo iniciaría la estancia Lago Fagnano. Germán Genskowski se dedicaría a la actividad ganadera y turística en la zona. Esta última actividad le haría recorrer, durante años, en tan sólo una temporada
Lucio había ido a Punta Arenas a comprar víveres, pero tuvo problemas con el regreso y tardó más de la cuenta, este sería su último el viaje a caleta María, porque ya se estaba retirando y tenía que volver a buscar a sus trabajadores Jorge Muñoz, "Pecho de toro", Arturo Vidal y familia recuerda Catalán. Fue por casualidad que el concesionario de la estancia Vicuña de aquel entonces, Jorge Quiñones, realizaba un recorrido en helicóptero por la zona junto a personal del Instituto Geográfico Militar, ellos aterrizaron en la pista de aterrizaje entonces nos acercamos a ellos y le explicamos la situación que había nacido un bebé y que los víveres escaseaban, entonces don Jorge Quiñones le pidió al piloto del helicóptero si podían ir a la estancia a buscar algunos víveres y regresar, el piloto dijo que no había ningún problema, después regresaron con víveres, nosotros le dimos muchas gracias comenta Catalán. Al poco tiempo pasó una embarcación particular que trasladó a Arturo Vidal, su señora y su hija hasta Porvenir, allí fueron ayudados por Francisco Gómez Andrade (1912-1995) quien finalmente les compró pasajes con destino a Punta Arenas.

\section{Fin del aserradero de Lucio Genskowski}

A fines de la década de 1960, el aserradero de Lucio Genskowski P. llegaba a su término, Germán Genskowski M. recuerda que en aquel tiempo, en 1969, mi madre quería que postulara a un trabajo en ENAP, yo no quería por que a mi me gustaba trabajar en el campo, pero para darle en el gusto postulé y más encima salí llamado, entonces mi padre me pidió que me retirara de caleta María porque la cosa ya estaba mala, el aserradero generaba grandes costos económicos difícil de solventar. Mi hermano Rodrigo se quedó trabajando junto a mi padre hasta el último. Mi padre se empecinó con el aserradero, sabía que la cosa no estaba bien pero el no quería abandonar y trabajó hasta el último momento que pudo. ${ }^{28}$

Uno de los escasos registros de la presencia de Lucio Genskowski y sus trabajadores en caleta María es un escrito de Carabineros de Chile de la Tenencia de Yendegaia que visitaron el lugar en 1969, a pesar

más de mil kilómetros cabalgando desde estancia "Vicuña" a lago Fagnano para ir a buscar y luego dejar a los turistas, principalmente extranjeros, en un tiempo donde no existía accesibilidad vehicular. 


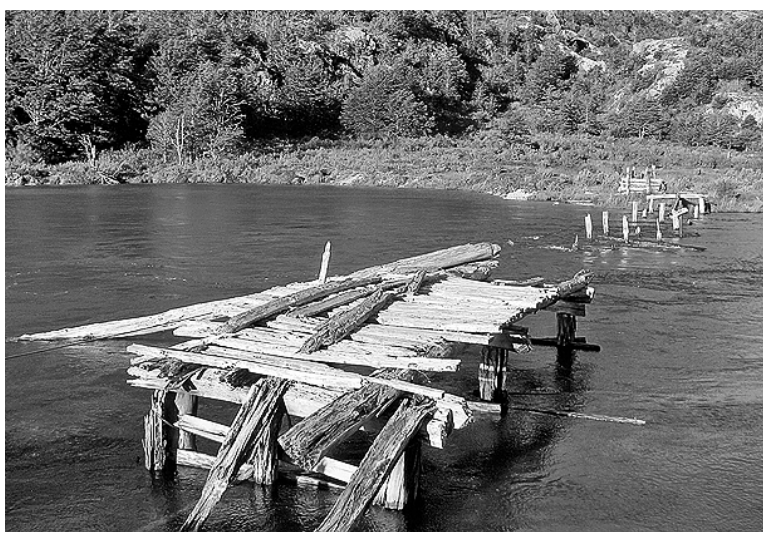

Fig.28. Vestigio de puente sobre el río Azopardo (Fotografía del autor, 2013).

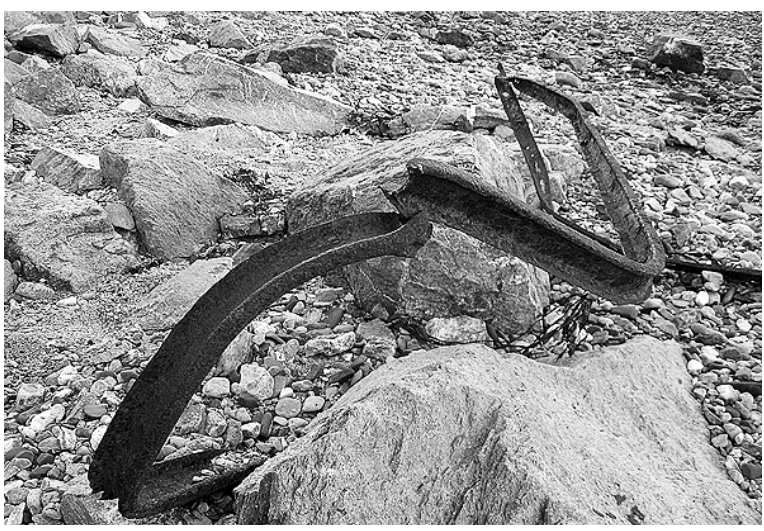

Fig.30. Restos de rieles a orillas del fiordo Almirantazgo (Fotografía del autor, 2013).

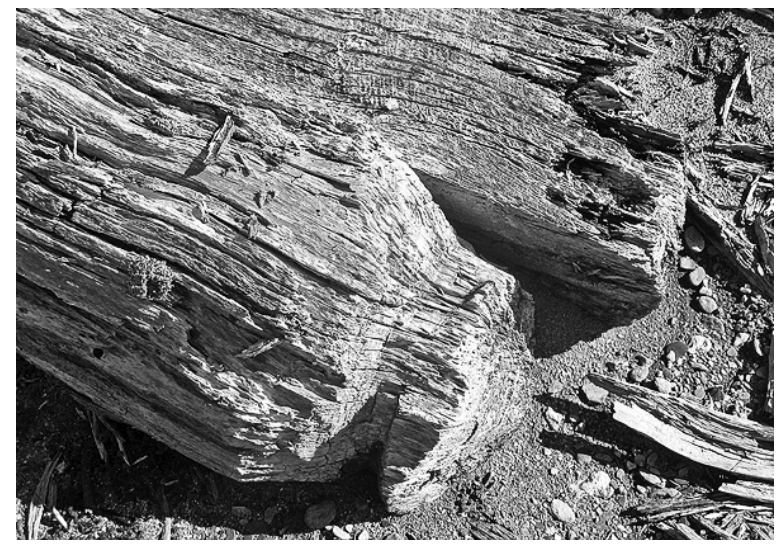

Fig. 32. Viga elaborada y viga en bruto a orillas del fiordo Almirantazgo (Fotografía del autor, 2013).

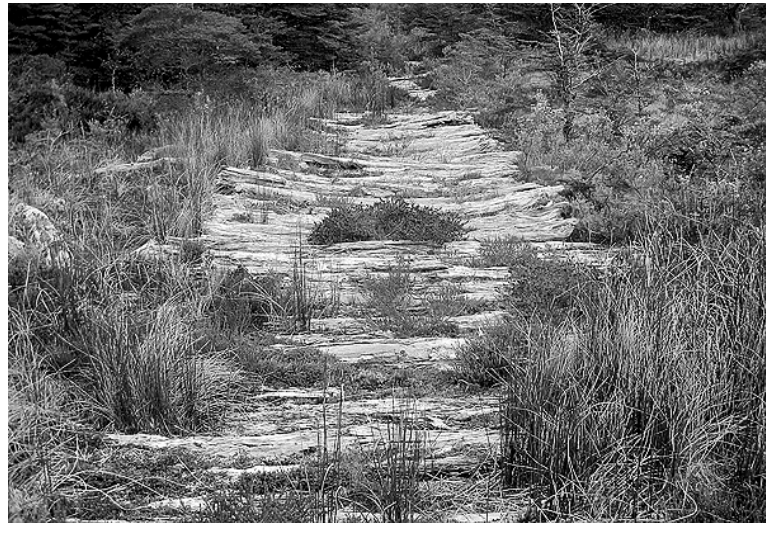

Fig.29. Planchado sobre el valle Fontaine (Fotografía del autor, 2013).

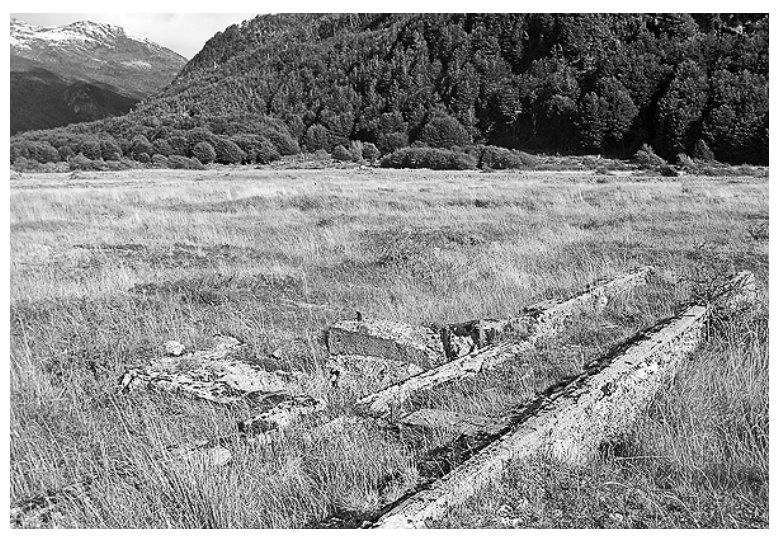

Fig.31. Restos de fundaciones del antiguo galpón del aserradero "Caleta María" (Fotografía del autor, 2013).

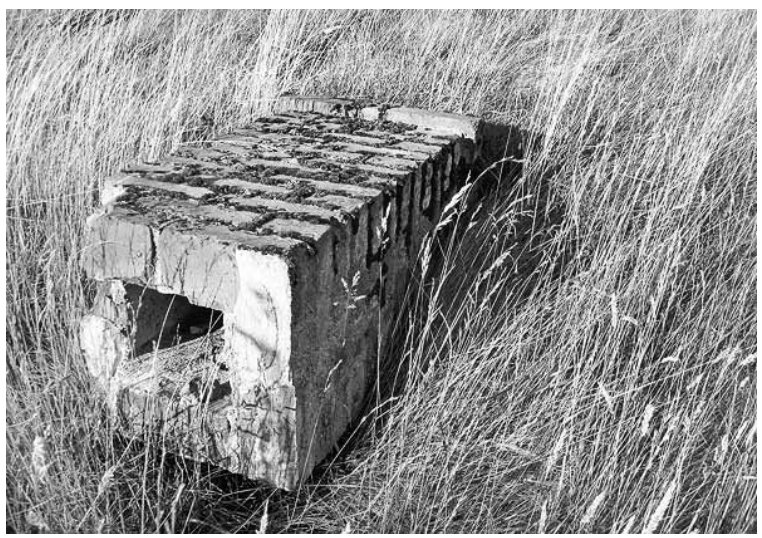

Fig.33. Vestigio de una chimenea construida con ladrillos Marcou (Fotografía del autor, 2013). 
que no entregan nombre de personas, no hay duda que eran Lucio y sus trabajadores.

\section{1 de febrero1969}

De guardia Carabinero José Gallardo

Se realizó un patrullaje en helicóptero hasta el seno Almirantazgo continuando hacia el lago Fagnano, hitos 22 y 23 para regresar a la hora anotada al destacamento.

Se trajo correspondencia de los pobladores de la Caleta María, que será enviada a Punta Arenas.

La hora de salida fue a las 9:50 hrs, llegando a las 11:25hrs a caleta María donde se almorzó y en la tarde se fiscalizó el sector de Fagnano

Carabinero José Gallardo/Fernando Álvarez Pinto, Teniente de Carabineros ${ }^{29}$.

Arturo Barrientos Leal

Cuando Lucio Genskowski se retiró de caleta María en 1973, traspasó sus derechos de ocupación a Arturo Barrientos Leal (1908- 1987) ${ }^{30}$. Barrientos se dedicó sólo a la crianza bovina con resultados pocos positivos. Entre los trabajadores de Arturo Barrientos se recuerda a Francisco Oyarzún, José Maldonado apodado "El Rubio" o "La Polaca", Sergio Ruiz Nahuelcar apodado Granizo, Mario Cum, Luís "Machete” Muñoz y un tal Leni.

Arturo Barrientos a diferencia de Lucio Genskowski no vivía permanentemente en caleta María, sólo iba en algunas temporadas durante el año junto a su hijo Arturito Barrientos. El único vecino que tenía Barrientos era Reinaldo Catalán ${ }^{31}$, según éste el problema que tuvo Barrientos, por el cual su negocio ganadero no tuvo buen resultado se debió que en un tiempo tuvo trabajadores pésimos que no sabian nada de animales y en vez de juntarlos los correteaban y nunca mas los capturaron. Entonces don Arturo hacía ventas de animales en Punta Arenas con pago anticipado, pero sus trabajadores que tenía en caleta María nunca lograban tener los animales para la venta. Así Barrientos se endeudó y un día llegaron los Carabineros a detenerlo a caleta María en 1978, de ahí no volvió más. En ese tiempo trabajaban para Barrientos el "rubio" el "granizo", Mario Cum y "Machete" Muñoz. Una vez Cum y Machete Muñoz se agarraron a peliar en un ranchito antiguo que después lo llamaban "rancho Barrientos”, este ranchito estaba donde está Germán Genskowski ahora en el lago Fagnano. Cum le tenía mucha envidia a Machete que ya era de edad. Una vez Cum le cortó las cinchas al caballo de Machete para que este se cayera y accidentará, cuando Machete se dio cuenta preguntó quién había sido y Cum le dijo: yo fui y te tengo ganas viejo de mierda, eso desató la pelea altiro que término en el interior del rancho Barrientos, si no hubiese llegado el "rubio" a separarlos, "Machete" Muñoz mata a Cum.

\section{Reinaldo Catalán Oporto}

Cuando Barrientos se retiró de caleta María, el lugar paso a ser fiscal y permaneció abandonado hasta que Reinaldo Catalán, baqueano por excelencia, se radicó allí en $1980^{32}$ y años más tarde, el 22 de octubre de $1993^{33}$ se convirtió en su legítimo dueño.

El mismo año en que Catalán se radicó en caleta María ocurrió la trágica muerte de Juan Agustín Fohmann Soto ${ }^{34}$ quien murió ahogado en la orilla sur del lago Fagnano el 27 de febrero de 1980 a los veintinueve años de edad. Fohmann conocido como el gringo Osman, trabajaba en la estancia "Gumalau", de Gustavo Leiva (actual estancia "Paso Bellavista") hace algún tiempo. En una oportunidad acompañó a Luis Covi N. y Francisco Oyarzún D. a colaborar con Catalán para capturar vacunos en la orilla sur del sector argentino del lago Fagnano. Al respecto Catalán agrega, yo les advertí al "gringo", a Covi y a Oyarzún que tuvieran cuidado en una puntilla que hay en una parte en lago, era un puntilla peligrosa y profunda, yo no los pude acompañar por que en ese momento guiaba a una patrulla de carabineros a Yendegaia. Cuando regresé me enteré de la mala noticia. Justamente el accidente ocurrió en ese lugar donde les dije que no se fueran a meter. Un toro que el "gringo" habia laceado lo arrastró con caballo y todo al lago, de allí no salió más, sólo quedó su sombrero flotando en

\footnotetext{
${ }^{29}$ Información inédita obtenida del Libro de Población 19671971 de la Tenencia de Yendegaia de Carabineros de Chile". Se agradece al Sargento Sergio Vásquez poder acceder a la información.

30 Garcia, 2012:67

${ }^{31}$ Ver nota 24

32 Ver nota 18.

33 Garcia 2012:71
} 
el agua, Covi llevaba el toro laceado desde atrás, pero alcanzó a cortar el lazo y se salvo (...) de allí Oyarzún fue a avisar al retén de Vicuña de lo que había pasado. Después que encontramos el cuerpo del gringo, porque nos demoramos harto en encontrarlo, demoramos 4 días en llevarlo hasta caleta María, como el gringo medía como 2 metros de altura nos costó harto llevar su cuerpo de a caballo, primero llevamos el cuerpo del hasta la desembocadura del lago Fagnano, ahí lo cruzamos en un puente colgante que yo había construido, los caballos pasaron a nado, me acompañaban Francisco Oyarzún y el carabinero Olivera, el puente estaba medio malo y parecía que nos ibamos todos a caer y yo dije en vez de ser uno vamos a ser tres más (...) después lo llevamos por la derecha del rio Azopardo y cruzamos por el puente antiguo al lado sur del río nuevamente, cerca de la desembocadura del río Mascarello, ya en caleta María lo llevamos en carreta hasta la casa que en ese tiempo estaba abandonada (...) estuve velando al gringo en la casa nueve días hasta que pasó un barco particular a caleta María y allí se conversó con ellos para que llevaran al cuerpo del gringo a Porvenir donde fue sepultado ${ }^{35}$. El gringo una vez robó unos caballos con el "indio Covi" de una estancia Argentina llamada "San Justo" cercana a la estancia "Gumalau" donde él trabajaba y los fue a esconder al lago Fagnano, los carabineros lo andaban buscando por el robo pero justo murió. Una vez escuché que los carabineros le habían dado muerte a balazos porque el "gringo" no se quizó entregar cuando lo querian detener,

34 Juan Agustín Fohmann Soto, nació el tres de junio de 1950 en Ancud, Chiloé. Sus padres fueron Ivar Fohmann Yiger (Ingeniero Agrónomo de profesión) y Lidiana Soto Corbett. Juan Fohmann fue el penúltimo de nueve hermanos y era apodado por sus familiares el "Cucho". Según su hermana Silvia, Juan Fohomann media dos metros seis de altura, rubio como la mantequilla, era muy buen hermano e hijo y llegó a la región de Magallanes porque tuvo que realizar, en contra de su voluntad, el servicio militar en Puerto Natales. Luego viajaría a Porvenir (Tierra del Fuego, Chile) y ya no volvería más a su tierra natal. Respecto a los actos y muerte de Juan Fohomann, en Tierra del Fuego, son muchas las versiones y los mitos que se han fundado entorno a él. En lo referido a su muerte, sus hermanas Silvia y Helena habían indagado que su hermano había sido baleado en el lago Fagnano porque había hurtado unos caballo y su cuerpo fue arrojado al lago Fagnano y después de tres meses unos buzos pero eso es mentira. También se decía que los gendarme argentinos lo andaban buscando por que les había quemado un galpón y robado unas monturas. Yo tenía muy buena relación con el "gringo", me tenía mucho cariño y me respetaba harto, siempre me decía don Reinaldo. Después de la muerte del "gringo" fuimos con "Arturito" Barrientos a dejar una cruz en un cerrito cerca del lugar donde murió [...] esa cruz la envió el finado Francisco Ojeda y Onorio Chiguay quienes estaban trabajando en la Paciencia y que habían conocido al "gringo".

Una vez radicado en Caleta María, Catalán siguió dedicándose a la crianza de vacunos y a recorrer solitariamente los sectores de caleta María, lago Fagnano, estancia Vicuña, también empezó a construir cercos, corrales, y todo lo necesario para realizar sus trabajos. La vida de Reinaldo Catalán cambio definitivamente cuando conoció a Sara Alvarado con quien se casaría en 1986. A pesar del aislamiento geográfico y la rigurosidad del clima en invierno, Sarita aceptó vivir en caleta María. Desde entonces la vida para Catalán fue distinta y junto a su esposa, caleta María se llenó de buenos momentos para ambos y sobre todo cuando nació su hija Karina (1990), quién crecería los primeros años de su vida en caleta María.

La presencia de Catalán en caleta María significó para muchos una gran ayuda, brindó hospitalidad, fue alcalde de mar, guió a expediciones ${ }^{36}$ entre la que destaca la realizada por Hans Niemeyer en 1978 cuyo objetivo era estudiar la factibilidad técnica de la construcción de un camino que uniera

lo sacaron del agua. Reinaldo Catalán afirma que lo del robo de los caballos es verdad, que los sacó junto a Luís Covi de la estancia "San Justo" (Tierra del Fuego, Argentina) y luego los llevaron hasta el lago Fagnano, pero que es mentira lo que se dice respecto a su muerte, primero porque Fohomann murió ahogado en lago Fagnano a causa de un accidente cuando estaba bagualeando junto a Francisco Oyarzún y Luís Covi en el sector argentino del lago Fagnano, a cuatro km. de la frontera con Chile, y segundo porque él junto a Luís Covi, el sargento de carabineros Luís Elgueta y el carabinero Olivera, fueron quienes encontraron y sacaron del agua el cuerpo de Juan Fohomann y no tenía indicios de balazos en su cuerpo.

${ }^{35}$ En febrero del 2013, junto a Patricio Díaz, pudimos corroborar, in situ, que efectivamente Juan Fohmann Soto fue sepultado en el cementerio de Porvenir. 


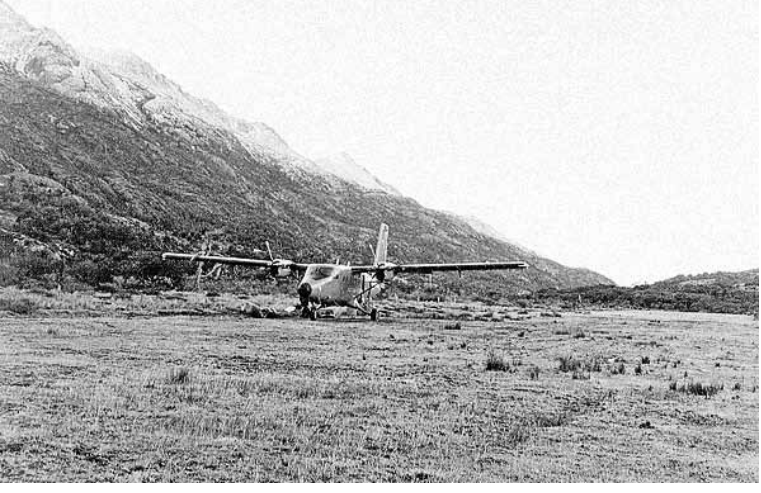

Fig.34. Avión en la cancha de aterrizaje de caleta María, 2003 (Fotografía gentileza de Julio Contreras).

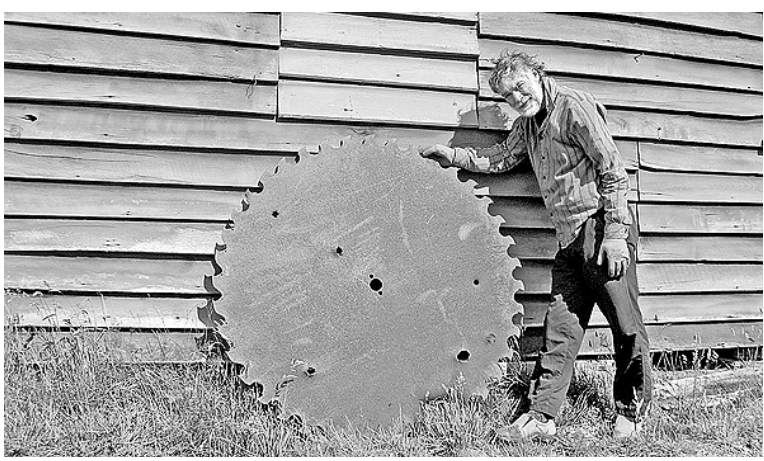

Fig.36. Sierra utilizada en el aserradero "Caleta María” (Fotografía del autor, 2013).

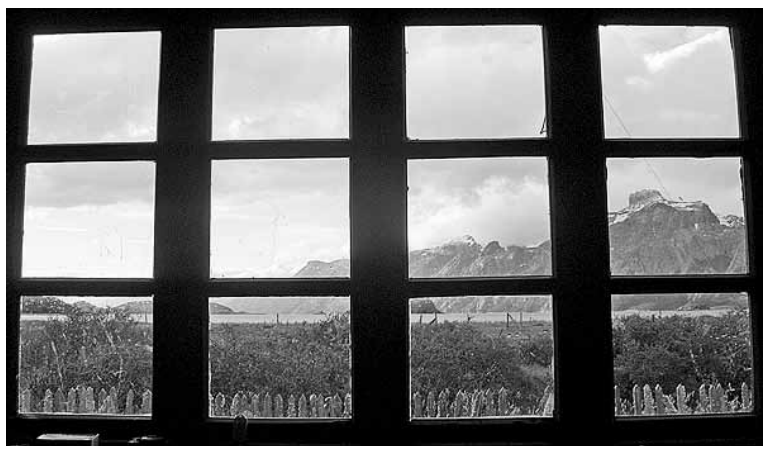

Fig.38. Vista desde el interior de la casa administración hacía el fiordo Almirantazgo (Fotografía del autor, 2013).

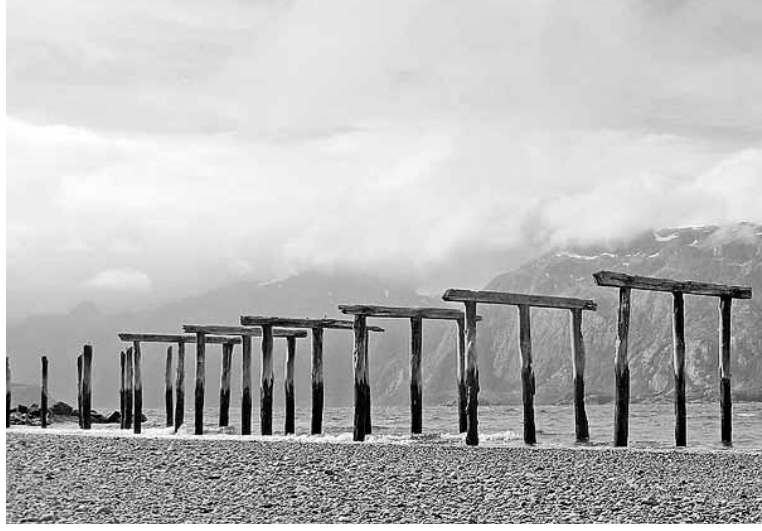

Fig.35. Vestigios del segundo muelle construido en caleta María (Fotografía del autor, enero 2011).

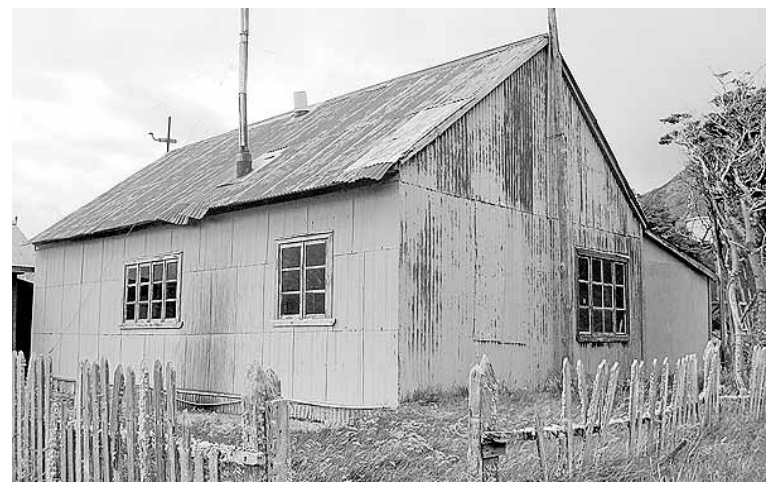

Fig.37. Casa administración del aserradero "Caleta María", construida en la década de 1950 (Fotografía del autor, 2013).

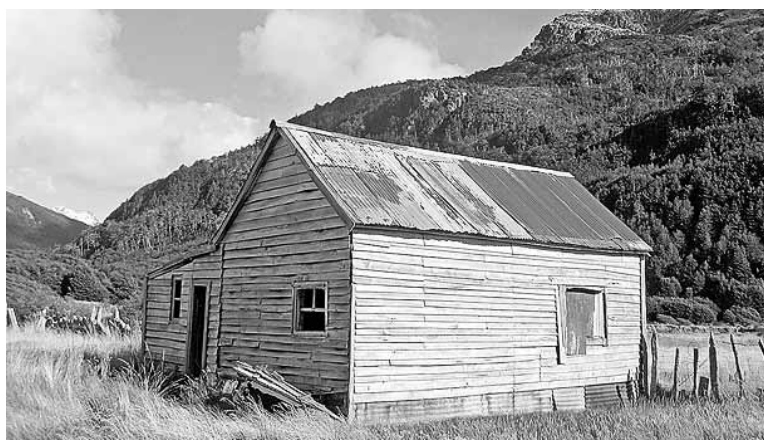

Fig.39. Vivienda en caleta María (Fotografía del autor, enero 2011). 


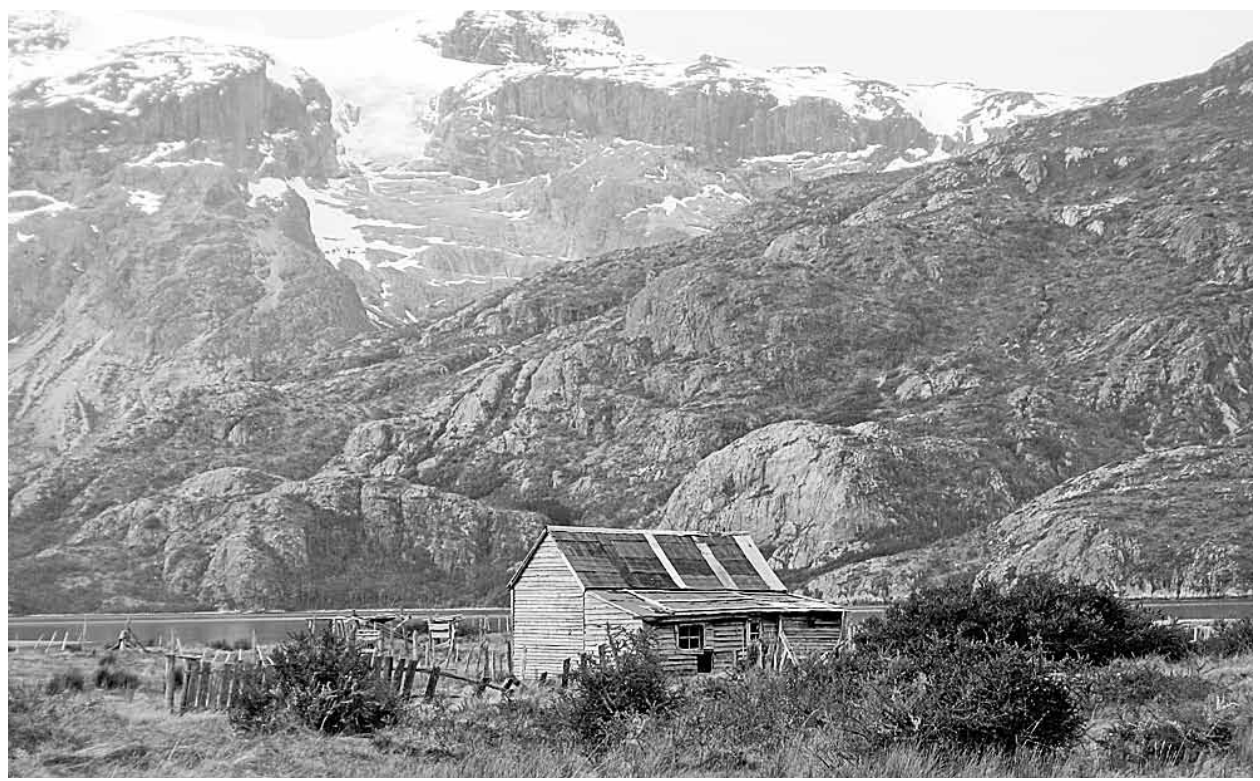

Fig.40. Vivienda en caleta María, al fondo se aprecia el ventisquero Veer (Fotografía del autor, enero 2011).

Vicuña-Yendegaia ${ }^{37}$. Siempre tuvo buenas relaciones con las fuerzas armadas, quienes lo admiraban por su labor de soberanía que realizaba en el sur de Tierra del Fuego. El vínculo y respeto de las fuerzas armadas hacía Catalán queda expuesto en una carta fechada el 22 de julio de 1988, escrita por el Capitán de Navio IM Comandante Jaime Marín Moreno:

Señor:

Reinaldo Catalán Oporto

Caleta Benavente

Presente

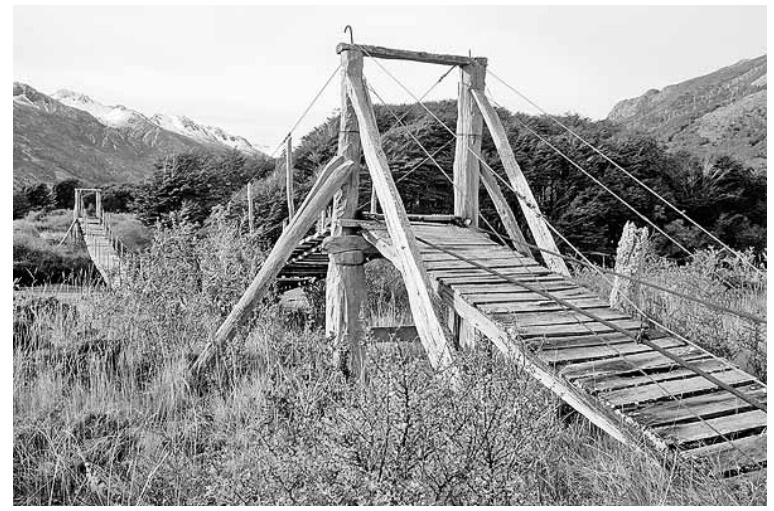

Fig.41. Puente sobre el río Fontaine construido por Alejandro Concha con la colaboración de Reinaldo Catalán en 1994 (Fotografía del autor, enero 2011).
De mi consideración:

Me dirijo a Ud., con el fin de solicitar su autorización para emplear parte de sus terrenos de Caleta Benavente ${ }^{38}$ - Río Azopardo, con el propósito de efectuar ejercicios, desde esta fecha $y$ hasta el 03 de agosto del presente año.

El empleo de munición de guerra, de armamento menor, necesario para el mejor entrenamiento de mi Unidad, será coordinado con Ud., por el Capitán de Corbeta IM Sr. Emilio Camacho Retamal.

Doy seguridad que de dispondrán las

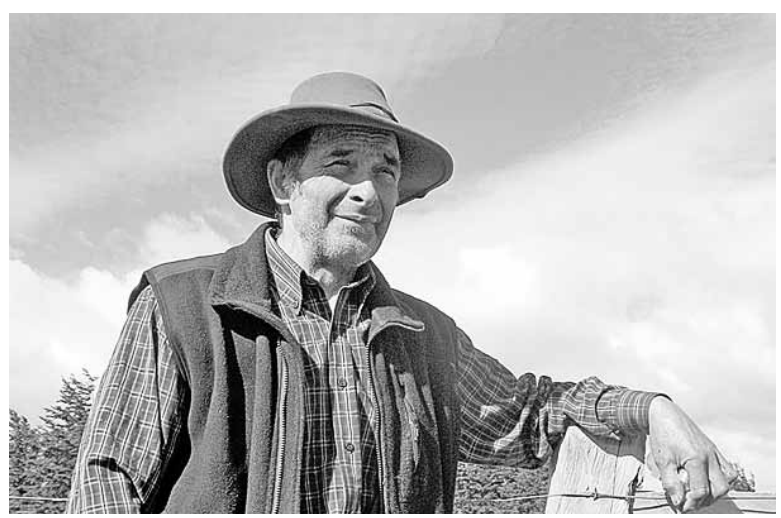

Fig.42. Germán Genskowski Middleton (Fotografía del autor, 2013). 


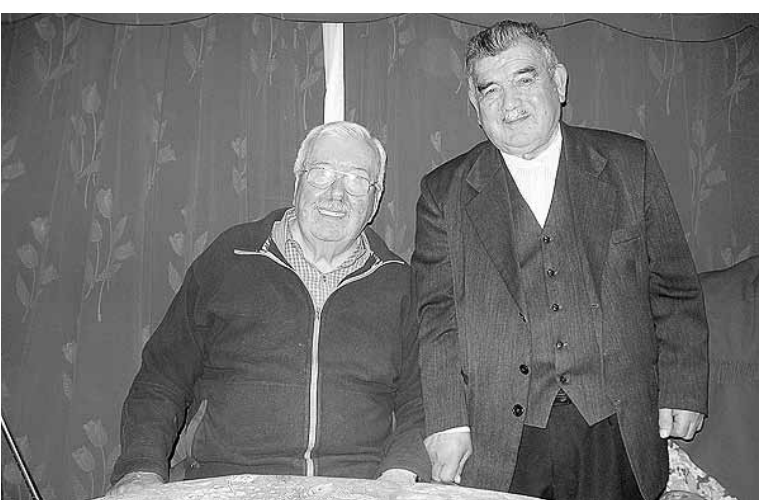

Fig.43. Juán kuzmanic y Reinaldo Catalán. Reencuentro después de 57 años (Fotografía del autor, abril 2012)

medidas necesarias para evitar daños a la flora y fauna del lugar.

A fines de 1997 Catalán decidió retirarse para siempre de Caleta María debido principalmente a problemas de salud. Primero se retiró su esposa y su hija el 7 de marzo de $1998^{39}$, él lo hizo más tarde en 2001 cuando terminó de sacar algunos de sus últimos vacunos. Catalán vendió sus terrenos a Julio Contreras con quien ha cimentado una fuerte amistad que se ha prolongado hasta la actualidad. Julio Contreras conoció caleta María en el invierno de 1996 cuando participó en una expedición, junto a cinco compañeros, que pretendía en pleno invierno unir Vicuña-Yendegaia. La desorientación geográfica en varias oportunidades hizo que la expedición se tornara tortuosa y larga. Así el grupo expedicionario decidió volver a la civilización por caleta María. Contreras sabía de la existencia de Catalán a quien quería conocer en persona pero lamentablemente

\footnotetext{
${ }^{36}$ Entre 1978 y 1987 Reinaldo Catalán realizó cinco expediciones desde Caleta María a Yendegaia, en las que siempre guió a expediciones militares. A continuación exponemos el registro de agradecimiento de la última expedición en la que participó. Punta Arenas, 20 enero 1987

La región Militar Austral agradece : al Señor Reinaldo Catalán Oporto en reconocimiento a su abnegada participación como integrante de la patrulla Tigre, que entre el 5 y el 18 de enero de 1987 cruzó con éxito la Isla Grande de Tierra del Fuego uniendo por Tierra, Porvenir con Yendegaia, en la ribera norte del canal Beagle.

37 Ver: Garcia 2012

${ }^{38}$ En los mapa de la Armada de Chile, caleta María figura como caleta Benavente.

${ }^{39}$ El ultimo viaje

Pero esto no tiene un final feliz. Ayer su señora, Sara Alvarado
}

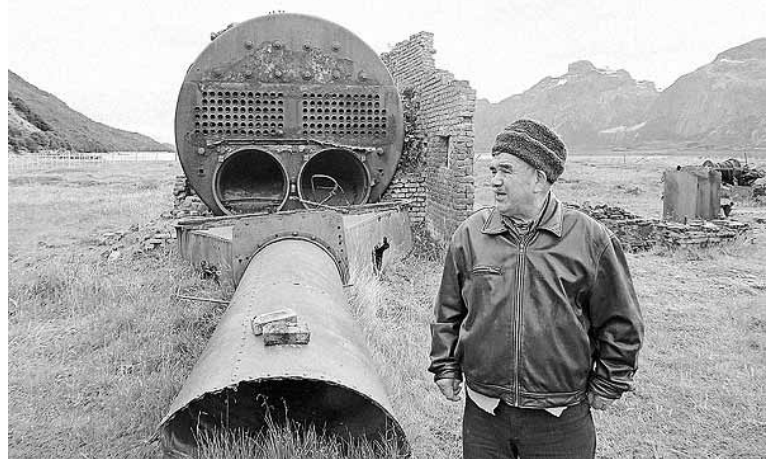

Fig.44. Reinaldo Catalán en caleta María, 2013 (Fotografía de Karina Catalán)

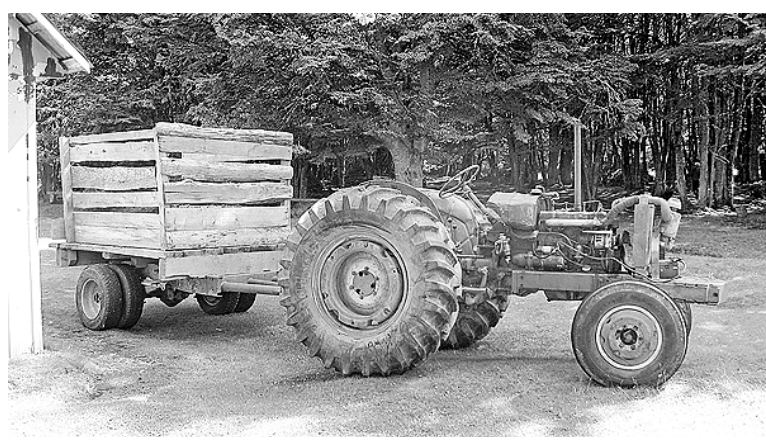

Fig.45. Tractor introducido al lago Fagnano por Lucio Genskowski en la década de 1960. (Fotografía del autor, estancia "Lago Fagnano" 2013).

Catalán en tal oportunidad estaba en Punta Arenas. Las cosas se fueron sucediendo sin presiones hasta que lograron conocerse y fue por la amistad y la confianza que Catalán tuvo y tiene a Julio Contreras que decidió venderle sus campos de caleta María. Catalán vió en

y su hija karina, vieron por última vez las cumbres del sector y el río que rondaba su casa, la decisión era dura, debían partir. Según, la señora Sara, las inclemencias del tiempo ya estaban calando hondo en la salud de todos y la niña necesitaba ingresar a la escuela. Atrás dejaban doce de convivencia mutua en la soledad de la Caleta para llegar a la ciudad, en donde Reinaldo quizás nunca se va acomodar.

De hecho el mismo, ha pedido a los actuales dueños que le permitan venir cada cierto tiempo a la zona y poder oler este aire frío que llega a "escarchar los bigotes y escuchar el zumbido del viento que es estable"

Al parecer, Reinaldo está atrapado en estas tierras y nunca podrá salir.

(Extracto del diario El Magallanes de la edición del 8 de marzo de 1998, pag. 9). 
Contreras una persona que no quería comprar solo para hacer explotación de los recursos naturales y tampoco para posteriormente venderla, sino una persona honesta y consciente cuyo compromiso es proteger caleta María y su entorno natural.

Con la retirada de Catalán de caleta María se da término a una historia de hombres y personajes que fueron construyendo historias no documentadas ni integradas como parte de las historias oficiales de Tierra del Fuego y que hoy empiezan a ser necesarias para entender los sucesos históricos y sociales desarrollados en tal distante territorio marginal. Si bien Catalán ya no vive en caleta María, su paso por ella siempre estará presente, bien lo escribió Ralf Oberti, camarógrafo del programa televisivo al fin del mundo luego de conocer a Catalán:

Caleta María , 12 de noviembre de 1997 Don Cata:

Siempre agradecido de su hospitalidad, buena compañía, hacedor de historias de este confín de la Tierra del Fuego.

Al momento de irnos me voy con el ánimo de volver a esta caleta María que Ud. a contribuido a construir, su fuerza y sabiduría perdurara en este lugar ahora que comienza a dejar a su querencia. Muchas Gracias.

Ralf A. O., camarógrafo del programa Al fin del Mundo. ${ }^{40}$

\section{LOS ÚLTIMOS VESTIGIOS}

Restos de antiguas instalaciones industriales desperdigadas actualmente por los campos de caleta
María nos sugieren que algo ha ocurrido. Una cancha de aterrizaje, planchados, rieles, ruedas de un locomóvil (Fig.26), restos fragmentados de fundaciones y de maquinarias industriales de la American Sawmill Machinery Company (Hackettstown, New Jersey, U.S.A.) y Clarke, Chapman and Company (Gateshead, England) (Fig.23), la estructura de un muelle, una caldera, ladrillos A. Marcou, antiguas casas en pie, vigas enperilladas, troncos cortados con hacha, cepas de un puente sobre el río Azopardo ${ }^{41}$ (Fig.28), hoy son valorados como vestigios patrimoniales que demuestran la existencia del tiempo.

El aserradero Caleta María fue el único aserradero del fiordo Almirantazgo que tuvo, aunque remota por cierto, cancha de aterrizaje $e^{42}$ (Fig.34). La caldera a vapor para el funcionamiento del aserradero (Fig. 21 y 22), perteneciente al entonces ex aserradero La Paciencia fue traída flotando a través del fiordo Almirantazgo desde aquel establecimiento industrial $^{43}$ emplazado en la bahía homónima. Los restos del muelle (Fig.35) que aún permanecen erigidos corresponden al segundo muelle construido por la firma Campos Menéndez, luego que el primero quedó sepultado bajo toneladas de piedras al desplomarse el cerro, al que iba bordeando, como consecuencia del terremoto del 17 de diciembre de 1949. Debido al poco calado de la bahía, la longitud del muelle superaba los $250 \mathrm{mts}$. convirtiéndose en el muelle más extenso de los aserraderos del fiordo Almirantazgo. Los cables de acero que sostenían la red para detener las vigas que bajaban por el río Azopardo desde el lago Fagnano, aún permanecen aferrados a las rocas, testimonio del paso imborrable del hombre (Fig.27). Por último podemos mencionar

un puente sobre el río Fontaine (visible en una fotografía de caleta María hacía 1945), de las dimensiones necesarias al igual que el resto de los puentes mencionados, para el tránsito de bueyes y carretas, este puente desapareció en 1990 a causa de una crecida del río Fontaine. Cabe señalar que sobre el río Azopardo existió otro puente que fue dibujado por Rockwell Kent en 1922, veinte años antes de la fundación del aserradero "Caleta María" (Kent 1924:74). Este puente es aún visible en la fotografía trigonométrica de la U.S.Airforce de 1945, según Reinaldo Catalán en 1955 no quedaba ningún vestigio de este puente.

42 Si bien el año de construcción de esta pista es desconocido al menos podemos mencionar que no fue construida antes de 1945, esto lo sabemos gracias a una fotografía trigonométrica del sobrevuelo de la U.S.Airforce de 1945 (Biblioteca Instituto de la Patagonia, Universidad de Magallanes).

${ }^{43}$ Dato proporcionado por Reinaldo Catalán y Germán Genskowski. 
que la casa que funcionó en los últimos años del aserradero como administración ${ }^{44}$, de volumetría simple y con un interior pensado para un habitar coherente con el contexto en que se inserta, recoge con una sutileza extraordinaria la potente macro geografía (Fig.37 y 38) a la se enfrenta.

Los vestigios patrimoniales del aserradero Caleta María se presentan hoy como huellas vulnerables del paso del hombre por un territorio que sirvió de soporte físico para que se desarrollaran distintas interacciones hombre-hábitat. Estos vestigios también pueden ser interpretados como objetos que reflejan una época donde la protección del patrimonio natural, en la práctica, no existía.

En la actualidad, caleta María al tener accesibilidad vía terrestre se presenta como un lugar que ofrece distintas posibilidades, por esto es necesario conocer y conservar su historia para poder actuar con un sentido histórico, contribuir a esto ha sido el verdadero objetivo de esta investigación. Esperamos que con el tiempo se sumen nuevos antecedentes y títulos que nos permitan tener un mayor conocimiento de caleta María y sus habitantes.

\section{AGRADECIMIENTOS}

A Reinaldo Catalán, Juan Kuzmanic, y sus respectivas familias, por compartir sus recuerdos de caleta María con el autor. Germán Genskowski M. y su esposa Marisela por permitirnos publicar las fotografías inéditas de Lucio Genskowski Pietrogrande y su siempre hospitalaria acogida en su estancia "Lago Fagnano". Don Mateo Martinic por la revisión del texto y sus sugerencias. A Nancy Varas Águila y familia (Porvenir), Jorge Leuquén (lago Deseado). Sergio Vásquez (Tenencia Yendegaia), Julio Contreras, Ivette Martínez. Ricardo Sánchez, Luís Gatica Cartes, Julio Flánega (CMT).

\section{FUENTES DE CONSULTA}

\section{a) Inéditas}

Fotografías históricas del aserradero "Caleta María" del autor Lucio Genskowski Pietrogrande.

Memorias de vida, capítulo referido a caleta María, y fotografías

\footnotetext{
${ }^{44}$ Este edificio ha sufrido ha sufrido varias modificaciones a lo
} largo del tiempo. de Juan Kuzmanic Stanicic.

Libro de Población 1967-1971, Tenencia Yendegaia de Carabineros de Chile.

\section{b) Impresas}

Agostini, A. (1956). Treinta años en la Tierra del Fuego. Buenos Aires: Peuser.

Baeriswyl, A. (2003). Arquitectura en Punta Arenas casas de maderas. Punta Arenas: Hielos Antárticos.

Belza, J. (1974). Tierra del Fuego: Colonización. Buenos Aires: Instituto de Investigaciones Históricas de Tierra del Fuego.

Braun-Menéndez, A. (1997). Pequeña historia fueguina. Buenos Aires: Francisco Aguirre.

García, S. (2012). Reinaldo Catalán y Francisco Oyarzún, baqueanos del sur de Tierra del Fuego (Chile) y su participación en el origen de la senda de penetración Vicuña-Yendegaia. Magallania, 40(1), 63-91.

Kent, R. (1924). Voyaging Southward from the Straits of Magellan. New York: Halcyon House.

Martinic, M. (2009). La Tierra de los Fuegos. Punta Arenas: Municipalidad de Porvenir.

Martinic, M. (1995). Cementerios y tumbas rurales en Magallanes. Magallania, 23, 5-40

Massa, L. (1950). Hacia el lago Fagnano: Cuarenta y cinco días a orillas del río Azopardo (Chile). Buenos Aires: Casa del Boletín Salesiano.

Niemeyer, H. (1978). Expedición de estancia Vicuña a bahía Yendegaia en la isla Grande de Tierra del Fuego. Expedición a Chile, cuaderno D1, fascículo 48. Santiago: Gabriela Mistral.

Otero, L. (2006). La huella del Fuego. Santiago: Pehuén.

Skottsberg, C. (2004). La Patagonia Salvaje. Ushuaia: Zagier y Urruty.

Toledo, N. (2010). 100 personajes históricos de Patagonia y Antártica. Punta Arenas: [s.e.].

c) Entrevistas

- Francisco Oyarzun Díaz (abril 2011).

- José Maldonado Maldonado (enero 2011).

- Juan Kuzmanic Stanicic (abril 2012).

- Reinaldo Catalán Oporto (marzo 2013).

- Germán Genskowski M (Febrero 2013).

- Arturo Vidal (marzo 2013).

- Luís Covi Nahualhaique (febrero 2013).

- Silvia Fohomann Soto (Julio 2013). 


\section{ANEXO I}

Entre los días 1 y 12 de marzo de 1994 los miembros de la Sociedad Chilena de Exploraciones (SOCHEX) Jorge Milla, Hernán Muñoz, Eduardo Jofré y Carlos Palacios realizaron una expedición que unió Pampa Guanaco con la bahía Yendegaia. Durante este viaje llegaron a caleta María donde pudieron compartir junto a Reinaldo Catalán y su familia. De esta experiencia Jorge Milla escribió en su bitácora de viaje algo más que un simple cuento basado en la vida de Catalán. El escrito refleja la atmosfera que inspiraba, hacía los afuerinos, la vida de Catalán en este apartado rincón de Tierra del Fuego y por eso nos parece oportuno exponerlo. También es importante aclarar que el diario La Prensa Austral de la edición del 16 de marzo de 1994 expuso en sus páginas que uno de los miembros de la SOCHEX afirmaba: (respecto a la expedición Pampa Guanaco-Yendegaia) sabíamos que era un trazado difícil que no había sido cubierto por ninguna expedición chilena. Esto es inexacto y fue un invento del periodista a cargo de la nota para darle un mayor realce a la noticia. Los miembros de la SOCHEX estaban en conocimiento de que no eran los primeros y es más, antes de realizar la expedición se entrevistaron, en Santiago, con Hans Niemeyer Fernández, quien había realizado esta misma ruta en $1978^{45}$.

Reinaldo Catalán Oporto, el hombre que creyó venir del Sur

En los confines más australes de Chile y del mundo, allá en Tierra del Fuego, aún señorean bestias formidables. Son los llamados baguales, enormes vacunos en estado salvaje. En el siglo pasado, y transportados por los primeros colonos en rústicas embarcaciones, llegaron a estas ignotas tierras en donde recuperaron la libertad. Intento vano por capturarlos, finalmente huyeron para sumergirse en lo profundo de bosques y montañas. Aquí se multiplicaron, crecieron, y más salvajes aún se hicieron. Pronto olvidaron el manso pasado en las extensas pasturas del norte, poco tiempo pasó,

\footnotetext{
${ }^{45}$ Ver García, 2012.

46 José Almonacid, en aquel entonces era trabajador de la estancia "Lago Fagnano" iniciada por Germán Genskowski en 1985 en la cabecera occidental y ribera norte del lago Fagnano.
}

y aquel indomable y bravío espíritu, - adormecido durante tantos siglos -, despertó otra vez con toda fuerza.

Es noche de febrero, animadamente conversamos sentados junto al calor de la cocina a leña-la estufa-como suelen llamarla acá. Nuestro anfitrión es Reinaldo Catalán, el más insigne Campañista de estas latitudes, para los amigos y desde ahora también para nosotros, será simplemente Don Cata. Ni siquiera el amargo sabor del mate que bebemos, logra distraernos y absortos escuchamos los relatos, solo interrumpidos cuando el turno de aspirar la bombilla corresponde al único narrador. Afuera, el viento patagónico ruge furioso agitando árboles y mar por igual. Desde la casa, claramente se escucha, el seco golpe de las olas castigando las soberbias laderas rocosas del fiordo Almirantazgo. Miles de años atrás, sus paredes fueron labradas durante el retroceso de masas de hielo colosales. La misma luna que contempló esa dramática formación, lo ilumina ahora, transformándolo a nuestra imaginación como abiertas mandíbulas de monstruosas fauces, listas para devorar.

En Patagonia, campañista es sinónimo de arriero, estirpe en extinción de hombres recios y diestros, los únicos capaces de soportar el rigor del fin del mundo. En su modesto hogar, es Don Cata persona amable, sencilla y cordial, siempre dispuesto a contar una vez más las aventuras acumuladas durante más de cincuenta años recorriendo contrafuertes y estribaciones de la cordillera de Darwin, y los innumerables cajones boscosos que transforman la zona en laberinto infernal. Por más de cinco décadas fue el único habitante existente en cientos de miles de kilómetros cuadrados "es el pequeño patio de mi casa", señala soltando una risotada a estas alturas familiar. Escuchándole se tiene total certeza que esta tierra no tiene secretos para él. Hace no muchos años, se estableció aquí, en su amada Caleta María, lugar donde las aguas color turquesas del hermoso río Azopardo, se unen para siempre con el mar.

Don Cata es del norte, las tranquilas tierras de Osorno le vieron alguna vez nacer, esas mismas tierras de donde probablemente también provienen los ancestros del bagual. Curiosa semejanza, hombre y bestia con historias tan increíblemente similares, llegaron a estas comarcas desde lejanas latitudes, despertó aquí en ambos lo originario otra vez. Desde el 
primer momento fueron mortales enemigos, furiosos adversarios, antagonistas furibundos, no importó la inmensidad, nunca hubo ni habrá espacio suficiente para los dos. Aquel impulso primitivo por defender el territorio les impide aceptar en sus dominios a todo competidor. Baguales y Don Cata lo son, por eso sostienen lucha que solo la muerte de uno de los dos, extinguirá.

"Varias veces lo he tenido en la mira del rifle", nos dice Don Cata refiriéndose a su enemigo, el gran toro negro de rojos ojos, "hemos estado frente a frente, solos los dos, sus enormes ojos rojos, inyectados de furia asesina, es algo difícil de olvidar...". También Plata, su noble y fiel caballo, conoce de la fiereza del bagual. Alguna vez, sorpresivamente saltó desde la espesura del bosque para embestir con inimaginable saña, solo la habilidad de Don Cata, les salvó aquella vez.

No se trataba de alusión genérica a los baguales, claramente se refería a uno en especial, un muy enorme y furioso toro bagual que recorría los bosques del lugar, el mismo animal que insolentemente había declarado como sus dominios exclusivos toda la extensa zona entre los ríos Azopardo y Lapataia. "El paso de las Lagunas es su lugar favorito para atacar, ahí no hay bosque en donde guarecerse así es que deben cruzar con mucha cautela, mañana les acompañaré hasta el portezuelo que existe más allá del río Fontaine, a partir de ese punto estarán solos en el dominio del gran bagual...".

Dicho esto, se levantó súbitamente de su asiento, y dio por terminado el relato, nosotros quedamos mirándonos sorprendidos. Jamás en nuestra planificación, estuvo comprendido algún análisis de peligros de este tipo, inimaginable hubiese sido solo pensar en que no era el terreno, el clima, o los ríos, los peligros objetivos del cruce. Era en cierto modo inaudito caer en la cuenta ahora, a mitad de camino de la expedición, que enfrentábamos un peligro objetivo de esta naturaleza. Pronto nos retiramos a dormir, no fue fácil, la conversación se extendió largamente discutiendo acerca de cómo, una persona, con su mochila al hombro, y a campo traviesa, cuyas únicas armas, son un par de bastones o un piolet, hace frente a la furiosa embestida de un animal de ochocientos kilos. Esa noche, no hubieron precisamente ovejas en nuestros sueños.

Al día siguiente, continuamos nuestra marcha rumbo a Yendegaia. Tal como lo había prometido don Cata, nos acompañó hasta aquel portezuelo desde donde se apreciaba casi por completo el formidable cajón del río Toledo. Allá lejos, donde la vista se perdía al oriente, a unos tres o cuatro días de marcha se adivinaba el paso hacia los cajones cordilleranos que conducirían al valle de Lapataia. Previo a despedirse nos recomendó extrema cautela y mantener la cota en el cerro, ni muy abajo para caer en los campos inundados por los castores, ni tan arriba para enredarse en los bosques aparragados. Lo vimos alejarse lentamente, hombre formidable en tierra formidable, conocerlo fue grande privilegio.

Nunca vimos al gran toro negro de ojos rojos, sentimos sí, permanentemente su presencia mientras avanzábamos hacia el sur, estamos seguros que muchas veces nos observó atento. Para nuestra fortuna nunca apareció, probablemente olfateó nuestro miedo y determinó que no éramos dignos adversarios, pusilánimes e insignificantes hombres urbanos de paso, eso y nada más. El contrincante verdadero, ese que jamás temor demostró, el perseguidor implacable, el único digno de enfrentase a su furia, era aquel campañista a quién apodaban don Cata.

El tiempo nos permitió entender que Don Cata y el gran bagual negro, se profesaban mutuo y solemne respeto. Hombre y bestia se reconocían como últimos poseedores del indomable espíritu de Tierra del Fuego, la muerte de uno, significaba la muerte de ambos, por eso tantas veces el rifle falló o la cornamenta esperando por sangre fresca quedó.

Desde aquella vez, he viajado muchas veces a esta maravillosa tierra, siempre dicen que es imaginación mía, que aquel poderoso bramido que escucho, es solo el viento, callo y nada digo, no tengo dudas, es el gran bagual, está allá en los montes, sus eternos dominios, desafía al campañista, honorable rival como el que nunca habrá más.

Fragmento de la bitácora de viaje a Tierra del Fuego. Cruce terrestre desde Pampa Guanacos a Bahía Yendegaia. Febrero de 1994. 


\section{ANEXO II}

INFORME DE RECONOCIMIENTO DE CALETA MARÍA PARA LA INSTALACIÓN DE UNA ALCALDIA DE MAR (1989)

Lugar: Caleta Benavente, Seno Almirantazgo (Ex caleta María)

Latitud: 54을 $29^{\prime} \mathrm{S}$

Longitud: 68 $59^{\prime} \mathrm{W}$

Fecha: 15 de junio 1989

Unidad: LPC 1804 "Villarrica"

Referencia:

Derrotero I.H.A. № 3004

Carta I.H.A. Res. № IX-1

Carta I.H.A № 1101

\section{I.- Datos Generales}

a) Geografía:

Caleta Benavente está situada en el saco del Seno Almirantazgo en la costa suroriental de la desembocadura del río Azopardo, a unos 2 metros sobre el nivel del mar.

La caleta en sí, posee unos 700 metros de terreno plano, apto para construir edificaciones.

El lugar está encerrado en su parte posterior por altos cerros rocosos (300 a 600 mts.) en cuyas faldas existen tupidos bosques de coihues. La costa inmediata del Seno Almirantazgo esta conformada por cumbre de altitud apreciable (sobre 600 mts.).

La playa que rodea a la caleta está en avanzado estado de embancamiento. El terreno de la playa está constituido por arena (de río) y huevillos de pequeño porte. La gradiente de la playa es suave y pareja, sin escollos.

Los vientos predominantes del NNW/W, se dejan sentir con fuerza sobre la caleta y sus inmediaciones.

b) Hidrografía:

El fondeadero para una patrullera tipo LPC, queda frente a las casas de la caleta, a unos $120 \mathrm{mts}$. de la rompiente; fondo de arena con fango, y en $12 \mathrm{mts}$. El tenedero no es recomendable debido a que está completamente abierto a los vientos reinantes. Puede encontrarse un surgidero de resguardo al sureste de isla Tres
Mogotes, pero se recomienda retromarchar y fondear en Caleta Stanley. La playa no es apta para barcazas LST, debido al embancamiento que esta experimenta. Como a $20 \mathrm{mts}$. de la rompiente se sondan aproximadamente $70 \mathrm{cms}$.

Por información de los lugareños, se dice que con heladas, frecuentes en el área, el mar se escarcha en una gran extensión, incluso esta llegaría hasta la inmediaciones de la isla Tres Mogotes.

La visual desde la caleta y hacia el Seno Almirantazgo, es reducida, pudiendo en parte, cubrir el área de este seno con apoyo radar.

c) Población:

En Caleta Benavente habitan las siguientes personas:

- Sr. Reinaldo Catalán Oporto

- Sra. Sara Alvarado Guerrero

- Sr. Alejandro Concha Ramírez

- Sra. Luisa Sobrasen de Concha

Todas estas personas habitan en un mismo inmueble. En general, la casa habitación, es espaciosa, limpia y ordenada, admite ampliaciones o transformaciones.

El Sr. José Almonacid es otro lugareño. Esta persona vive a $4 \mathrm{hrs}$. de caleta Benavente; en la ribera del río Azopardo, en dirección al lago Fagnano ${ }^{46}$.

d) Infraestructura:

En caleta Benavente, existe una casa habitación amplia y abrigada, de madera en su totalidad, habitada por dos matrimonios. La vivienda posee dos piezas disponibles, ocupadas para alojamiento.

El alumbrado es en base a una instalación de dos acumuladores de gas. No existen motor eléctrico o generadores de gas. Como medio secundario de alumbrado se utilizan las velas de cera comunes.

El agua proviene de un pozo cercano a la vivienda. El sistema sanitario es en base a dos pozos sépticos. En las cercanías de la casa hay otras cinco construcciones, todas semidestruidas y que son utilizadas como bodegas de usos diversos.

Existe un muelle de unos $80 \mathrm{mts}$. de 
largo que se encuentra destruido, por lo tanto inoperativo.

e) Recursos

La leña es abundante.

El abastecimiento de víveres y gas deber ser realizado por vía marítima.

Hay abundancia de mariscos y crustáceos $y$ en menos escala pescado.

La playa de la caleta es de arena y existe un sector de esta con gran cantidad de huevillos; todo este material podría ser utilizado en construcción.

La masa ganadera es poco significativa: 80 vacunos, 15 lanares, 2 porcinos, 2 caballares $y$ aves de corral. Estos animales son utilizados para reproducción y consumo de la población.

No existe implementación de primeros auxilios.

f) Comunicaciones:

La recepción de radioemisoras locales es buena.

La LPC VILLARRICA efectuó prueba de comunicaciones con MAGALLANES RADIO con los siguientes resultados:

\begin{tabular}{|c|c|c|}
\hline FRECUENCIA & INTENSIDAD & $\underline{\text { APRECIACION }}$ \\
5385 & 2 & Regular \\
5300 & 2 A 3 & Satisfactorio \\
2950 & NIL & Malo \\
\hline
\end{tabular}

Las condiciones atmosféricas eran: Regulares, nubes bajas, visibilidad $6 \mathrm{~km}$. Por otra parte, hay que considerar que la cadena montañosa circundante está constituida por cerros de altitud apreciable.

Se enlazó con NATALES RADIO, experimentándose mejoría en Tx y Rx (mismas frecuencias anteriores).

Por información de poblador local, el antiguo aserradero de caleta Benavente utilizó una antena de radio. Hay vestigios de partes de las bases de la antena pero en pésimo estado de conservación. Esta se encuentra al costado de la

\footnotetext{
${ }^{47}$ Fecha errónea, el terremoto fue el 17 de diciembre de 1949.

${ }^{48}$ En 1990 Reinaldo Catalán fue designado Alcalde de Mar de caleta María, cargo que desempeñó hasta el 2001.
}

vivienda. Se estima que la altura de la antena debe haber sido unos $15 \mathrm{mts}$. de altura.

En la actualidad, en caleta Benavente $e$ inmediaciones no existe ningún equipo de comunicación. Cualquier información debe ser canalizada a través de pesqueros o naves de la Armada que recalan en forma esporádica; o en su efecto a Carabineros de la Bahía Yendegaia, lugar distante a 4 días (a caballo).

\section{g) Varios:}

Distante a $3 \mathrm{~km}$. de caleta Benavente, existe una pista de aterrizaje, de tierra y unos $700 \mathrm{mts}$. de largo; sin infraestructura de apoyo. En dicho lugar han aterrizado aviones de fuselaje mediano del Ejército y FACH.

La energía eólica puede ser considerada como fuente de energía, debido a que el área es reconocidamente ventosa.

Los lomajes ubicados atrás de las viviendas, son de mejor accesibilidad que los que la rodean por la ribera sur de la caleta, pudiéndolos considerar como posibles puntos de ubicación de antenas.

Hay constancia que en $1948^{47}$ hubo un fuerte temblor en el área; el cual originó derrumbe $y$ destrucción de algunas viviendas de la caleta. Esto se puede apreciar en las cercanías del antiguo muelle, ya que hay grandes bloques de piedras desprendidas y amontonadas.

\section{II.- APRECIACIÓN GENERAL}

Caleta Benavente esta situada en un lugar de fácil y expedito acceso por vía marítima y aéreo; no así por vía terrestre, ya que no existe camino de interconexión con algún otro poblado de Isla Grande de Tierra del Fuego.

Seno Almirantazgo, es una amplia vía marítima a la cual acceden una cantidad reducida de embarcaciones y naves, las que realizan labores de soberanía, pesca y turismo.

La estación de radio más cercana a caleta Benavente se encuentra en la base naval de Puerto Harris, distante 65 millas náuticas.

Los pobladores carecen de medio de comunicación radial, lo que constituye una grave situación, del punto de vista de la seguridad personal. Por otra parte cualquier embarcación que se encuentre en el área y requiera apoyo en 
caso de alguna emergencia, se encontraría inerte y sin capacidad de reacción.

Finalmente, este mando estima que, resultaría altamente positivo el contar con un medio de comunicación en caleta Benavente; con el fin último de constituirse este como medio gravitante en apoyo a la población asentada y el tráfico marino que confluye al área, ambos preocupantemente abandonados de medio de enlace y comunicación ${ }^{48}$.

PUNTA ARENAS, 27 de junio 1989

ERWIN MIRANDA LEYTON

TENIENTE SEGUNDO LT

CAPITAN LPC 1804 VILLARRICA

\section{ANEXO III}

\section{CONCESIONES DE ALEJO SEGUNDO MARCOU EN EL SUR DE TIERRA DEL FUEGO}

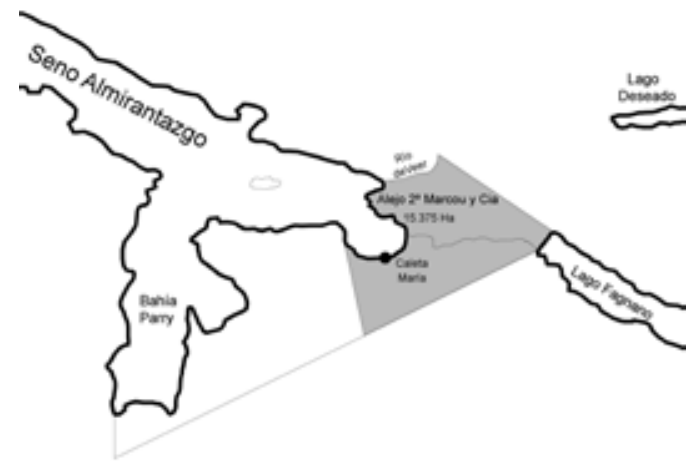

Fig.46. Mapa redibujado por el autor a base de un plano inédito, sin año y identificación, probablemente hacia 1915. Mapateca Instituto de la Patagonia.

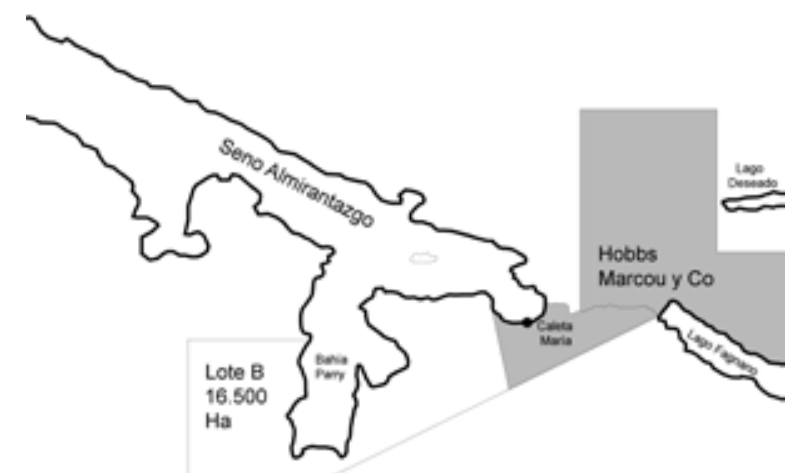

Fig.47. Mapa redibujado por el autor a base del plano titulado: Parte del Territorio de Magallanes con la subdivisión de Tierras. Escala 1:500.000. Ministerio de Fomento, Chile, Departamento de Tierras y Colonización 1928. Mapateca Instituto de la Patagonia.

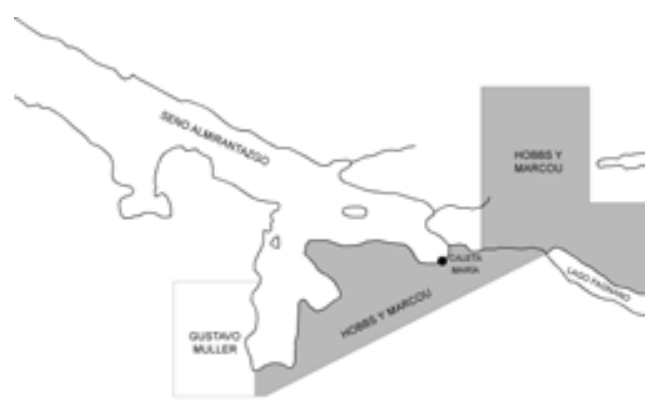

Fig.48. Mapa redibujado por el autor a base del plano titulado: Ubicación de Establecimientos Ganaderos Representados por la Sociedad Dick y Bravo 1:500.000. 1930. Mapateca Instituto de la Patagonia. 